ks. dr hab. Kazimierz Skoczylas ${ }^{1}$

Uniwersytet Mikołaja Kopernika

\title{
Odniesienie młodzieży XXI wieku do wartości na przykładzie młodzieży Kujaw wschodnich
}

Wartości są przedmiotem zainteresowania różnych wychowawców. Internalizacja wartości powoduje, że osoba staje się wewnątrzsterowna. Uznane i zaakceptowane wartości mają znaczący wpływ na zachowanie, sposób postępowania, podejmowane decyzje i kształt przyszłego kierunku życia. Zatem wychowawcy pragną, aby wychowankowie przyjęli preferowane w danym systemie wartości.

Młodzież przejmuje wartości w sposób selektywny od poprzednich pokoleń. Na jej wybory mają wpływ silne trendy kulturowe, tradycja i wychowanie w rodzinie, dokonujące się procesy społeczne. Dziś, na początku XXI wieku, w klimacie wolności i ogromnego dostępu do dóbr materialnych i wszechobecnej reklamy, wydaje się, że na znaczeniu zyskują wartości materialne.

Dla wychowawców ważne staje się pytanie: jakie wartości przyjmuje młodzież żyjąca w centralnej części Polski?

1 Ks. dr hab. Kazimierz Skoczylas - adiunkt w Katedrze Teologii Praktycznej na Wydziale Teologicznym Uniwersytetu Mikołaja Kopernika. Zajmuje się katechetyką. W swoich badaniach wiele uwagi poświęca młodzieży i jej stosunkowi do wartości. E-mail: kskoczylas@diecezja.wloclawek.pl. 
Wartości są również przedmiotem stałego zainteresowania różnych dziedzin nauki. Interesują się nimi filozofowie, socjologowie, psychologowie, teologowie czy historycy. Podejmowano wiele prób określenia wartości. W tym artykule będę posługiwał się przyjętą w socjologii religii definicją operacyjną wartości. Taka definicja precyzuje sposób pomiaru danego zjawiska. Wskazuje ona działania, operacje badawcze, które będziemy wykonywać ${ }^{2}$. Często przez wartości rozumie się w socjologii „odziedziczone przez osoby w procesie socjalizacji, w kulturowym kontekście określonego społeczeństwa, zinternalizowane standardy, które służą jako kryteria ocen i preferencji faktów społecznych, opinii, przekonań oraz zasad postępowania"'.

Tak rozumiane wartości są efektem dokonującej się socjalizacji zarówno pierwotnej, jak i wtórnej. Nie są one wydedukowanymi konstruktami myślowymi. Tworzą się i narastają w określonym kontekście historyczno-kulturowym, w określonym miejscu i czasie. Gdy nabierają znaczenia i uznania na płaszczyźnie społecznej, stają się wartościami społecznymi. One również nadają sens, identyfikację, motywację zarówno jednostkom ludzkim, jak i społeczeństwom ${ }^{4}$. Przyjmuje się, że funkcjonują dwa systemy wartości - wartości osobowe i wartości społeczne ${ }^{5}$.

Wartości osobowe mają swoją specyfikę. Wśród nich jedne są dla danej osoby szczególnie ważne i decydują o orientacji życiowej. One zazwyczaj nadają kierunek ludzkiemu życiu. Nazywa sięje wartościami ostatecznymi. W ich zakres mogą wchodzić religia, rodzina, praca, pomyślność, znalezienie sensu swojego życia. Wartości osoby zaś zorientowane na funkcjonowanie jej w społeczeństwie nazywane są wartościami życia codziennego ${ }^{6}$.

W porządku osobowym wartości, jak ujmuje to Władysław Piwowarski, są wartości ostateczne i codzienne. Wartości ostateczne są określane przez orientację życiową jednostki. Obejmuje ona swoim zakresem cele

2 Por. E. Babbie, Badania społeczne w praktyce, przeł. W. Betkiewicz, Warszawa 2003, s. 146.

3 Por. K. Ryczan, Wartości katolików w tym środowiska miejskiego, Lublin 1992, s. 25-26.

4 K. Ryczan, Wartości katolików a typ środowiska miejskiego, dz. cyt., s. 26.

5 Por. W. Piwowarski, Stosunek uczniów i studentów do podstawowych wartości społeczeństwa polskiego, „Życie Katolickie” 9 (1990) nr 2, s. 64.

6 Por. K. Ryczan, Wartości katolików a typ środowiska miejskiego, dz. cyt., s. 27. 
dalsze i bliższe. W społeczeństwie polskim, według Piwowarskiego, można mówić o trzech typach orientacji na wartości. Pierwszy typ obejmuje orientację związaną z sacrum. Drugim jest orientacja odnosząca się do świata profanum. Osoby o takim nastawieniu poszukują sensu życia w wartościach humanistycznych, które są przez nich absolutyzowane. Trzecim typem jest orientacja konsumpcyjna. Osoby o takim nastawieniu poszukują wartości mogących zaspokoić ich potrzeby egzystencjalne ${ }^{7}$.

Drugi porządek wartości tworzą wartości społeczne. Jeśli wartości te są powszechnie akceptowane, wówczas traktuje się je jako wartości podstawowe. One umożliwiają jedność społeczną w zasadniczych sprawach. Traktowane są jako fundament porozumienia i działania społecznego. W wartościach tych społeczeństwo i państwo poszukują identyfikacji i sensu. W Polsce, zdaniem Piwowarskiego, wartości podstawowe wywodzą się z trzech wielkich tradycji. Pierwszą jest tradycja narodowa i historia. $Z$ tego nurtu wywodzi się religia, patriotyzm, wolność i suwerenność. Drugi nurt, z którego czerpią wartości podstawowe, to wartości eksponowane najsilniej przez rewolucję francuską, amerykańską i kultywowane przez prądy socjalistyczne. Akcentuje się tu sprawiedliwość, równość i zabezpieczenie społeczne. Trzeci nurt, z którego wywodzą się wartości podstawowe, to nowsze ruchy społeczne, które artykułują godność człowieka, prawa człowieka, prawdę, solidarność i pokój.

\section{Podmiot badania}

Przedmiotem zainteresowania są wartości młodzieży mieszkającej na terenie Kujaw wschodnich. Chodzi tu o tę część Kujaw, która po rozbiorach należała do zaboru rosyjskiego. Pokrywa się ona z północnym terenem diecezji włocławskiej do linii Wisły. Centrum Kujaw wschodnich stanowi Włocławek. Jego rozwój był powiązany właśnie z tą

7 Por. W. Piwowarski, Stosunek uczniów i studentów do podstawowych wartości społeczeństwa polskiego, dz. cyt., s. 225.

8 W. Piwowarski, Stosunek uczniów i studentów do podstawowych wartości społeczeństwa polskiego, dz. cyt., s. 65. 
częścią Kujaw. Kujawy były urodzajnym terenem rolnym. Stąd spławiano Wisłą do Gdańska zboże i inne płody, a potem sprzedawano na Zachód. Przyśpieszało to rozwój miasta. W XIX wieku we Włocławku zaczął rozwijać się przemysł, dość szybko wzrastała liczba ludności. Obok Polaków mieszkali tu Niemcy zajmujący się przemysłem i Żydzi świadczący bardzo różne usługi. Rozwój miasta przyśpieszała też zbudowana pod koniec XIX wieku kolej żelazna łącząca je z Warszawą i Bydgoszcząa ${ }^{9}$.

Jedną z cech charakterystycznych Włocławka jest skupienie na jego terenie znaczącej liczby szkół średnich. Zjawisko to istniało już w okresie międzywojennym. Szkoły średnie rozwinęły się tutaj dość licznie po odzyskaniu prze Polskę niepodległości. W tym czasie miasto liczyło około 70 tys. mieszkańców. W latach 1918-1939 funkcjonowały następujące szkoły: Państwowe Gimnazjum Ziemi Kujawskiej, Państwowe Gimnazjum im. Marii Konopnickiej, Gimnazjum im. ks. Jana Długosza, Gimnazjum im. Piusa X, Gimnazjum ss. Urszulanek, Gimnazjum Koedukacyjne Gminy Żydowskiej, Państwowa Niższa Szkoła Techniczna, Państwowa Szkoła Handlowa, Miejska Szkoła Zawodowa ${ }^{10}$. Po drugiej wojnie światowej miasto się rozrastało i zwiększała się liczba szkół.

Na koniec XX wieku miasto Włocławek osiągnęło około 120 tys. mieszkańców. Wzrosła też liczba szkół średnich. Oprócz istniejących powstawały nowe szkoły ogólnokształcące i szkoły techniczne. Służyły one zarówno młodzieży Włocławka, jak i całemu regionowi Kujaw wschodnich. W roku 2012 było we Włocławku 11 dużych zespołów szkół średnich. Można szacować, że w tym czasie uczęszczało do nich około 9700 młodzieży z tego terenu. (W roku szkolnym 2016/17 we wrześniu 2016 było 9292 uczniów w szkołach ponadgimnazjalnych. Rocznie ubywa około 100 osób spośród uczniów szkół średnich. Dane uzyskano w Urzędzie Miasta 31.01.2017).

Sondaż diagnostyczny w tej grupie młodzieży został zrealizowany w maju 2012 roku. Do zbierania informacji posłużono się ankietą Wartości

9 Por. M. Morawski, Monografia Włocławka, Włocławek 2003, wyd. 2, s. 83-162; por. także S. Kalembka, Kujawy Wschodnie w powstaniu styczniowym. Rys wybranych zagadnień, w: Z dziejów powstania styczniowego na Kujawach i Ziemi dobrzyńskiej, red. S. Kalembka, Warszawa 1989, s. $12-14$.

10 Por. M. Morawski, Monografia Włocławka, dz. cyt., s. 322-326. 
a młodzież. W badaniu wzięło udział 864 uczniów. Rozdano około 1000 ankiet, zwrócono około 900. Do dalszego opracowania przyjęto 864 ankiety. W grupie respondentów było 493 kobiety i 371 mężczyzn, 563 uczyło się w liceach ogólnokształcących i 301 w szkołach zawodowych, 280 osób pochodziło ze średniego miasta powyżej 100 tys. mieszkańców. Ta grupa młodzieży ze średniego miasta będzie przedmiotem naszego zainteresowania. Badana młodzież należy do wyznania katolickiego. Wychowuje się w rodzinach, gdzie przywiązanie do wiary jest nadal dość silne ${ }^{11}$. Wśród respondentów 65,2 proc. stanowią licealiści, a 34,8 proc. uczy się w różnych typach szkół zawodowych. Jeżeli chodzi o miejsce zamieszkania to 39,1 proc. mieszka na wsi, 13,7 proc. w małym mieście, 14,8 proc. w średnim mieście, zaś 32,4 proc. w dużym mieście ${ }^{12}$.

$\mathrm{Na}$ terenie tego miasta prowadzone jest duszpasterstwo parafialne. Sieć parafii jest dość rozbudowana. We Włocławku funkcjonuje 15 parafii. W duszpasterstwie parafialnym pracuje około 49 księży oraz ponad 80 nauczycieli religii we wszystkich typach i poziomach szkół ${ }^{13}$.

\section{Praktyki religijne badanych}

Najpierw zwrócono uwagę na praktyki religijne badanych. Starano się poznać, jak często młodzież uczestniczy w niedzielnej mszy świętej, jak często się spowiada, jak często modli się osobiście oraz jaki odsetek uczestniczy w lekcji religii.

11 Por. K. Skoczylas, Wartości religijno-moralne młodzieży ponadgimnazjalnej Kujaw wschodnich, Włocławek 2016 s. 73-74.

12 K. Skoczylas, Wartości religijno-moralne..., dz. cyt., s. 86-87.

13 Por. „Rocznik Diecezji Włocławskiej 2011”, red. A. Niemira, Włocławek 2011, s. $127-291$. 
Tabela 1. Częstotliwość uczestnictwa we mszy świętej w ciągu roku a płeć respondenta ${ }^{14}$

\begin{tabular}{|c|c|c|c|c|}
\hline \multirow{2}{*}{\multicolumn{2}{|c|}{$\begin{array}{l}\text { CZĘSTOTLIWOŚĆ UCZESTNICTWA } \\
\text { WE MSZY ŚWIĘTEJ W CIĄGU ROKU }\end{array}$}} & \multicolumn{2}{|c|}{ PŁEĆ RESPONDENTA } & \multirow{3}{*}{\begin{tabular}{|c|} 
OGÓłEM \\
130 \\
\end{tabular}} \\
\hline & & \multirow{2}{*}{$\begin{array}{c}\mathrm{K} \\
80 \\
\end{array}$} & \multirow{2}{*}{$\begin{array}{l}\mathrm{M} \\
50\end{array}$} & \\
\hline \multirow{2}{*}{ 1. W każdą niedzielę } & Liczebność & & & \\
\hline & \% z płeć respondenta & $16,2 \%$ & $13,5 \%$ & $15,0 \%$ \\
\hline \multirow{2}{*}{ 2. Prawie w każdą niedzielę } & Liczebność & 135 & 52 & 187 \\
\hline & $\%$ z płeć respondenta & $27,4 \%$ & $14,0 \%$ & $21,6 \%$ \\
\hline \multirow{2}{*}{ 3. $1-2$ razy w miesiącu } & Liczebność & 71 & 60 & 131 \\
\hline & \% z płeć respondenta & $14,4 \%$ & $16,2 \%$ & $15,2 \%$ \\
\hline \multirow{2}{*}{ 4. Tylko w wielkie święta } & Liczebność & 75 & 78 & 153 \\
\hline & $\%$ z płeć respondenta & $15,2 \%$ & $21,0 \%$ & $17,7 \%$ \\
\hline \multirow{2}{*}{ 5. Tylko z okazji ślubu, pogrzebu } & Liczebność & 64 & 55 & 119 \\
\hline & $\%$ z płeć respondenta & $13,0 \%$ & $14,8 \%$ & $13,8 \%$ \\
\hline \multirow{2}{*}{ 6. Wcale } & Liczebność & 20 & 36 & 56 \\
\hline & $\% \mathrm{z}$ płeć respondenta & $4,1 \%$ & $9,7 \%$ & $6,5 \%$ \\
\hline \multirow{2}{*}{ 7. Trudno mi powiedzieć } & Liczebność & 31 & 27 & 58 \\
\hline & \% z płeć respondenta & $6,3 \%$ & $7,3 \%$ & $6,7 \%$ \\
\hline \multirow{2}{*}{ 8. Brak danych } & Liczebność & 17 & 13 & 30 \\
\hline & $\%$ z płeć respondenta & $3,4 \%$ & $3,5 \%$ & $3,5 \%$ \\
\hline \multirow{2}{*}{$\begin{array}{l}\text { Ogółem } \\
\text { \% z płeć respondneta }\end{array}$} & Liczebność & 493 & 371 & 864 \\
\hline & $100,0 \%$ & $100,0 \%$ & $100,0 \%$ & $100,0 \%$ \\
\hline
\end{tabular}

We mszy świętej w każdą niedzielę uczestniczy 15 proc., zaś 21,6 proc. badanych podało, że jest na mszy świętej prawie w każdą niedzielę, wcale nie chodzi do Kościoła 6,5 proc. Jednak 31,5 proc. (praktycznie co trzeci z badanych) mocno zaniedbuje uczestnictwo we mszy świętej. Tę grupę tworzą ci, którzy są na mszy świętej tylko w wielkie święta, oraz ci, którzy chodzą z okazji ślubu czy pogrzebu. Wydaje się, że wśród tej młodzieży zaangażowanie religijne najprawdopodobniej na dalszym etapie życia się nie zmieni.

14 Por. K. Skoczylas, Wartości religijno-moralne..., dz. cyt., s. 167. 
Tabela 2. Częstotliwość uczestnictwa we mszy świętej w ciągu roku a stosunek do praktyk religijnych ${ }^{15}$

\begin{tabular}{|c|c|c|c|c|c|c|}
\hline \multirow{2}{*}{\multicolumn{2}{|c|}{$\begin{array}{l}\text { CZĘSTOTLIWOŚĆ UCZESTNICTWA } \\
\text { WE MSZY ŚWIĘTEJ W CIĄGU ROKU }\end{array}$}} & \multicolumn{4}{|c|}{$\begin{array}{c}\text { STOSUNEK } \\
\text { DO PRAKTYK RELIGIJNYCH* }\end{array}$} & \multirow{3}{*}{\begin{tabular}{|l} 
OGÓŁEM \\
130 \\
\end{tabular}} \\
\hline & & \multirow{2}{*}{\begin{tabular}{r|}
1 \\
117 \\
\end{tabular}} & \multirow{2}{*}{$\begin{array}{r}2 \\
9 \\
\end{array}$} & \multirow{2}{*}{3} & \multirow{2}{*}{$\begin{array}{r}4 \\
24 \\
\end{array}$} & \\
\hline & Liczebność & & & & & \\
\hline 1. W każdą niedzielę & $\begin{array}{l}\% \text { z stosunek do praktyk } \\
\text { religijnych }\end{array}$ & $45,9 \%$ & $3,2 \%$ & $0,8 \%$ & $2,2 \%$ & $15,0 \%$ \\
\hline \multirow{2}{*}{$\begin{array}{l}\text { 2. Prawie w każdą } \\
\text { niedzielę }\end{array}$} & Liczebność & 98 & 71 & 13 & 5 & 187 \\
\hline & $\begin{array}{l}\% \text { z stosunek do praktyk } \\
\text { religijnych }\end{array}$ & $38,4 \%$ & $25,6 \%$ & $5,4 \%$ & $5,4 \%$ & $21,6 \%$ \\
\hline \multirow{2}{*}{$\begin{array}{l}\text { 3. 1-2 razy w mie- } \\
\text { siącu }\end{array}$} & Liczebność & 13 & 87 & 28 & 3 & 131 \\
\hline & $\begin{array}{l}\text { \% z stosunek do praktyk } \\
\text { religijnych }\end{array}$ & $5,1 \%$ & $31,4 \%$ & $11,7 \%$ & $3,3 \%$ & $15,2 \%$ \\
\hline \multirow{2}{*}{$\begin{array}{l}\text { 4. Tylko w wielkie } \\
\text { święta }\end{array}$} & Liczebność & 14 & 60 & 74 & 5 & 153 \\
\hline & $\begin{array}{l}\% \text { z stosunek do praktyk } \\
\text { religijnych }\end{array}$ & $5,5 \%$ & $21,7 \%$ & $30,8 \%$ & $5,4 \%$ & $17,7 \%$ \\
\hline \multirow{2}{*}{$\begin{array}{l}\text { 5. Tylko z okazji ślu- } \\
\text { bu, pogrzebu }\end{array}$} & Liczebność & 3 & 19 & 62 & 35 & 119 \\
\hline & $\begin{array}{l}\text { \% z stosunek do praktyk } \\
\text { religijnych }\end{array}$ & $1,2 \%$ & $6,9 \%$ & $25,8 \%$ & $38,0 \%$ & $13,8 \%$ \\
\hline \multirow[b]{2}{*}{ 6. Wcale } & Liczebność & 3 & 6 & 18 & 29 & 56 \\
\hline & $\begin{array}{l}\text { \% z stosunek do praktyk } \\
\text { religijnych }\end{array}$ & $1,2 \%$ & $2,2 \%$ & $7,5 \%$ & $31,5 \%$ & $6,5 \%$ \\
\hline \multirow{2}{*}{$\begin{array}{l}\text { 7. Trudno mi powie- } \\
\text { dzieć }\end{array}$} & Liczebność & 5 & 18 & 25 & 10 & 58 \\
\hline & $\begin{array}{l}\% \text { z stosunek do praktyk } \\
\text { religijnych }\end{array}$ & $2,0 \%$ & $6,5 \%$ & $10,4 \%$ & $10,9 \%$ & $6,7 \%$ \\
\hline \multirow[b]{2}{*}{ 8. Brak danych } & Liczebność & 2 & 7 & 18 & 3 & 30 \\
\hline & $\begin{array}{l}\text { \% z stosunek do praktyk } \\
\text { religijnych }\end{array}$ & $0,8 \%$ & $2,5 \%$ & $7,5 \%$ & $3,3 \%$ & $3,5 \%$ \\
\hline \multirow{2}{*}{$\begin{array}{l}\text { Ogółem } \\
\text { \% z stosunek do } \\
\text { praktyk religijnych }\end{array}$} & Liczebność & 255 & 277 & 240 & 92 & 864 \\
\hline & $100,0 \%$ & $100,0 \%$ & $100,0 \%$ & $100,0 \%$ & $100,0 \%$ & $100,0 \%$ \\
\hline
\end{tabular}

$\mathrm{Chi}^{2}=75,898 \quad \mathrm{df}=21 \quad \mathrm{p}=0,000 \quad$ V Kramera $=0,171 \quad \mathrm{p}=0,000$

* Uwaga: Cyfry w kolumnie stosunek do praktyk religijnych oznaczają: 1 - praktykuję systematycznie; 2 - praktykuję niesystematycznie; 3 - praktykuję rzadko; 4 - nie praktykuję wcale.

15 K. Skoczylas, Wartości religijno-moralne..., dz. cyt., s. 168-169. 
Patrząc na uczestnictwo we mszy świętej przez stosunek do praktyk religijnych, można zauważyć, że najgorliwsi są praktykujący systematycznie. Spośród tej grupy 45,9 proc. w każdą niedzielę uczestniczy we mszy świętej. W grupie praktykujących niesystematycznie uczestnictwo we mszy świętej przesuwa się do kategorii uczestniczenie 1-2 razy w miesiącu (31,4 proc.). Rzadko praktykujący chodzą na mszę świętą zazwyczaj tylko w wielkie święta (30,8 proc.), a niepraktykujący wcale zazwyczaj wcale (31, proc.) oraz z okazji ślubu lub pogrzebu (38 proc.).

Praktykujący systematycznie chodzą do spowiedzi najczęściej raz w miesiącu (47,8 proc.), praktykujący niesystematycznie raz w roku (41,2 proc.), praktykujący rzadko raz na kilka lat (26,3 proc.), a niepraktykujący odpowiadali, że najczęściej wcale się nie spowiadają (35,9 proc.) ${ }^{16}$.

Modlitwa jest najczęściej praktykowana w gronie osób praktykujących systematycznie (46,7 proc.), praktykujący niesystematycznie modlą się od czasu do czasu (20,9 proc.), a praktykujący rzadko nie modlą się najczęściej wcale (29,6 proc.). Niepraktykujący także najczęściej nie modlą się wcale $(58,7 \text { proc. })^{17}$.

Tabela 3. Udział w katechizacji a stosunek do praktyk religijnych ${ }^{18}$

\begin{tabular}{|c|c|c|c|c|c|c|}
\hline \multirow{2}{*}{\multicolumn{2}{|c|}{ UDZIAE W KATECHIZACJI }} & \multicolumn{4}{|c|}{$\begin{array}{c}\text { STOSUNEK } \\
\text { DO PRAKTYK RELIGIJNYCH* }\end{array}$} & \multirow{3}{*}{$\begin{array}{c}\text { OGÓŁEM } \\
581 \\
\end{array}$} \\
\hline & & 1 & 2 & 3 & 4 & \\
\hline \multirow[b]{2}{*}{ 1. Tak, regularnie } & Liczebność & 194 & 195 & 148 & 44 & \\
\hline & $\begin{array}{l}\text { \% z stosunek do praktyk } \\
\text { religijnych }\end{array}$ & $76,1 \%$ & $70,4 \%$ & $61,7 \%$ & $47,8 \%$ & $67,2 \%$ \\
\hline \multirow[b]{2}{*}{ 2. Tak, nieregularnie } & Liczebność & 22 & 27 & 33 & 9 & 91 \\
\hline & $\begin{array}{l}\text { \% z stosunek do praktyk } \\
\text { religijnych }\end{array}$ & $8,6 \%$ & $9,7 \%$ & $13,8 \%$ & $9,8 \%$ & $10,5 \%$ \\
\hline \multirow[b]{2}{*}{ 3. Wcale nie } & Liczebność & 9 & 17 & 14 & 19 & 59 \\
\hline & $\begin{array}{l}\text { \% z stosunek do praktyk } \\
\text { religijnych }\end{array}$ & $3,5 \%$ & $6,1 \%$ & $5,8 \%$ & $20,7 \%$ & $6,8 \%$ \\
\hline
\end{tabular}

16 K. Skoczylas, Wartości religijno-moralne..., dz. cyt., s. 174-175.

17 K. Skoczylas, Wartości religijno-moralne..., dz. cyt., s. 180-181.

18 K. Skoczylas, Wartości religijno-moralne..., dz. cyt., s. 185-186. 


\begin{tabular}{|c|c|c|c|c|c|c|}
\hline \multirow{2}{*}{\multicolumn{2}{|c|}{ UDZIAE W KATECHIZACJI }} & \multicolumn{4}{|c|}{$\begin{array}{c}\text { STOSUNEK } \\
\text { DO PRAKTYK RELIGIJNYCH* }\end{array}$} & \multirow{3}{*}{$\begin{array}{c}\text { OGÓŁEM } \\
114\end{array}$} \\
\hline & & 1 & 2 & 3 & 4 & \\
\hline \multirow{2}{*}{$\begin{array}{l}\text { 4. Trudno mi powie- } \\
\text { dzieć }\end{array}$} & Liczebność & 25 & 34 & 41 & 14 & \\
\hline & $\begin{array}{l}\text { \% z stosunek do praktyk } \\
\text { religijnych }\end{array}$ & $9,8 \%$ & $12,3 \%$ & $17,1 \%$ & $15,2 \%$ & $13,2 \%$ \\
\hline \multirow{2}{*}{ 5. Brak danych } & Liczebność & 5 & 4 & 4 & 6 & 19 \\
\hline & $\begin{array}{l}\% \text { z stosunek do praktyk } \\
\text { religijnych }\end{array}$ & $2,0 \%$ & $1,4 \%$ & $1,7 \%$ & $6,5 \%$ & $2,2 \%$ \\
\hline \multirow{2}{*}{$\begin{array}{l}\text { Ogółem } \\
\text { \% z stosunek do prak- } \\
\text { tyk religijnych }\end{array}$} & Liczebność & 255 & 277 & 240 & 92 & 864 \\
\hline & $100,0 \%$ & $100,0 \%$ & $100,0 \%$ & $100,0 \%$ & $100,0 \%$ & \\
\hline
\end{tabular}

$\mathrm{Chi}^{2}=57,784 \quad \mathrm{df}=12 \quad \mathrm{p}=0,000 \quad$ V Kramera $=0,149 \quad \mathrm{p}=0,000$

*Uwaga: Cyfry w kolumnie stosunek do praktyk religijnych oznaczają: 1 - praktykuję systematycznie; 2 - praktykuję niesystematycznie; 3 - praktykuję rzadko; 4 - nie praktykuję wcale.

Praktykujący systematycznie w 84,7 proc. uczestniczą w katechezie, praktykujący nieregularnie w 80,1 proc., praktykujący rzadko w 75,5 proc., a niepraktykujący w 57,6 proc. Najczęściej w katechizacji nie uczestniczą niepraktykujący (20,7 proc.). Stosunek do praktyk religijnych różnicuje uczestnictwo w katechezie w sposób statystycznie bardzo istotny.

Z przedstawionych danych można wyciągnąć wniosek, że wielu młodych dość systematycznie uczestniczy w katechezie, ale nie uczestniczy regularnie we mszy świętej niedzielnej, niezbyt często modli się i spowiada.

\section{Akceptacja prawd wiary}

W ankiecie zadano młodzieży szereg pytań dotyczących ich odniesienia do prawd wiary zawartych w wyznaniu wiary. Najważniejsze odpowiedzi na te pytania przedstawiono w sposób uproszczony poniżej w tabeli 4. 
Tabela 4. Akceptacja prawd wiary przez młodzież Kujaw wschodnich ${ }^{19}$

\begin{tabular}{|l|c|c|}
\hline \multicolumn{1}{|c|}{ PRAWDA WIARY } & LICZBA & PROCENT \\
\hline 1. Wiara w istnienie Boga osobowego & 442 & $51,2 \%$ \\
\hline 2. Wiara w Trójcę Świętą & 494 & $57,2 \%$ \\
\hline 3. Wiara w stworzenie świata & 533 & $61,7 \%$ \\
\hline 4. Wiara w stworzenie człowieka & 474 & $54,9 \%$ \\
\hline 5. Wiara w opatrzność Bożą & 502 & $58,1 \%$ \\
\hline 6. Wiara w Jezusa Chrystusa & 653 & $75,5 \%$ \\
\hline 7. Wiara we wcielenie i odkupienie przez Chrystusa & 600 & $69,4 \%$ \\
\hline 8. Wiara w zmartwychwstanie umarłych & 556 & 66,4 \\
\hline 9. Wiara w nagrodę lub karę po śmierci & 478 & $55,3 \%$ \\
\hline 10. Wiara w istnienie piekła & 512 & $59,3 \%$ \\
\hline
\end{tabular}

W powyższej tabeli przedstawiono całościowe zestawienie odniesienia młodzieży do prawd wiary wyznawanych w Credo. Pominięto część odpowiedzi, a przytoczono tylko te, które wskazują na wyraźną akceptację tych prawd. Stosunek respondentów do poszczególnych prawd wiary jest zróżnicowany. Najsilniej akceptowana jest prawda, że Jezus jest Synem Bożym i zarazem Bogiem człowiekiem. Przytoczone zestawienie wskazuje także, że znaczna część młodych z dużego miasta akceptuje podstawową treść wiary katolickiej. Najwyższy poziom akceptacji uzyskuje uznawanie Bóstwa i człowieczeństwa Jezusa Chrystusa (66,4 proc.) oraz wiara w Jego wcielenie i odkupienie (60,4 proc.). Niższy poziom akceptacji zyskują wiara w Trójcę Świętą (46,4 proc.), stworzenie człowieka (47,5 proc.) oraz wiara w nagrodę lub karę po śmierci (51,4 proc.).

\section{Wartości moralne}

Wartości moralne mają wpływ na ludzkie zachowania. O tym decyduje sumienie człowieka. Sumienie odpowiednio uformowane decyduje o ludzkich wyborach. Chrześcijanie opierają swój system wartości

19 K. Skoczylas, Wartości religijno-moralne..., dz. cyt., s. 122-153. 
na Dekalogu i wartościach objawionych przez Chrystusa. Stąd w sondażu starano się poznać, na ile młodzież kieruje się zasadniczymi wartościami moralnymi istotnymi dla chrześcijaństwa.

W relacjach międzyludzkich często zdarza się, że człowiek potrzebuje pomocy innych. Niesienie pomocy jest przejawem akceptacji dla przykazania miłości. Postawy wobec udzielania pomocy są zróżnicowane. Jedni są gotowi pomagać drugiej osobie w sposób bezinteresowny. Inni są skłonni pomagać wtedy, gdy im to się opłaca.

W całej populacji respondentów najczęstsze jest przekonanie, że dobrze jest pomagać innym nawet wtedy, gdy nic się z tego nie ma (44,1 proc.). Stosunkowo częsta jest motywacja interesowna (dobrze jest pomagać, bo potem można liczyć na pomoc innych - 33,9 proc.). Wśród głęboko wierzących najpopularniejsze jest przekonanie, że powinno się pomagać bezinteresownie (50,2 proc.), Praktykujący niesystematycznie sądzą najczęściej (41,2 proc.), że dobrze jest pomagać, bo można potem liczyć na pomoc innych. Praktykujący rzadko zaś i niepraktykujący wcale najczęściej mówią o pomocy bezinteresownej.

Wdzięczność jest postawą odpłacenia za dobro nam czynione, jest wezwaniem także do czynienia dobra i zadośćuczynienia za otrzymane dobro. Chrześcijaństwo wychowuje do wdzięczności. Wśród respondentów najczęstsze jest przekonanie, że pomagając innym, nie powinno się brać pod uwagę, czy ktoś się odwdzięczy, czy nie (46,9 proc.). To przekonanie jest najczęstsze w grupach 1, 2 i 3. Ono też jest najczęstsze pośród młodzieży Włocławka (48,2 proc.).

W codziennym postępowaniu każdej osobie towarzyszy świadomość jej obowiązków. Taką świadomość powinni mieć także młodzi katolicy. Najwyraźniejsza jest świadomość, że trzeba kochać Boga - zarówno wśród praktykujących systematycznie (49 proc.), jak i praktykujących niesystematycznie (50,2 proc.). Niepraktykujący (46,7 proc.) najczęściej nie potrafili powiedzieć, jaki jest najważniejszy obowiązek katolika. Stosunek do praktyk różnicuje postawy w sposób statystycznie bardzo istotny.

W relacjach społecznych wielką wartość ma zaufanie. Na nim buduje się ogromna liczba relacji społecznych. Brak zaufania utrudnia albo nawet uniemożliwia życie codzienne poszczególnych osób i odniesienia społeczne. Zmienna, jaką jest stosunek do praktyk religijnych, ujawnia, 
że osób bezgranicznie gotowych zaufać innym ludziom jest najwięcej wśród praktykujących systematycznie (19,2 proc.). Natomiast najliczniejsza jest grupa osób o ograniczonym zaufaniu (ufać można tylko temu, kogo się dobrze poznało), zarówno wśród praktykujących systematycznie (55,7 proc.), jak i niepraktykujących (52,2 proc.), zaś najbardziej nieufną postawę prezentują niepraktykujący (25 proc. - nie należy wierzyć ludziom, ufać można tylko sobie samemu). Stosunek do praktyk różnicuje omawiane postawy w sposób statystycznie bardzo istotny ${ }^{20}$.

\section{Przykazania Dekalogu}

Przykazania Dekalogu są akceptowane przez respondentów z różną intensywnością. Najwyższy poziom akceptacji zyskują przykazanie: czwarte (czcij ojca i matkę swoją), piąte (nie zabijaj) oraz siódme (nie kradnij). Poziom akceptacji określa procent osób, które uważają, że przykazania mają w życiu zastosowanie całkowite, oraz tych, które twierdzą, że tylko częściowe.

Postawy wobec Dekalogu różnicuje w sposób statystycznie bardzo istotny płeć. Płeć wprowadza takie zróżnicowanie wobec każdego przykazania Dekalogu. Kobiety znacznie częściej niż mężczyźni wyrażają akceptację dla poszczególnych przykazań. Miejsce zamieszkania różnicuje postawy wobec przykazania pierwszego, drugiego, trzeciego i czwartego. W stosunku do pozostałych przykazań nie ma ono takiego znaczenia, nie wprowadza różnic statystycznie istotnych. Stosunek do praktyk religijnych obejmuje postawy od „praktykuje systematycznie” do „nie praktykuję wcale". Z przeprowadzonych analiz wynika, że stosunek do praktyk religijnych różnicuje postawy wobec wszystkich przykazań Dekalogu. Zazwyczaj osoby określające siebie jako „praktykujący systematycznie” najczęściej wyrażają całkowitą akceptację dla poszczególnych przykazań Dekalogu. Osoby określające siebie jako „niepraktykujący” albo

20 K. Skoczylas, Wartości religijno-moralne..., dz. cyt., s. 211-230. 
„praktykujący rzadko” znacznie rzadziej wyrażają całkowitą akceptację dla kolejnych przykazań Dekalogu ${ }^{21}$.

\section{Stosowanie norm moralnych w codzienności}

Akceptacja wartości ujawnia się najczęściej przez konkretne wybory $\mathrm{w}$ wielu codziennych sytuacjach życia. Wybory w tych okolicznościach wskazują na znaczenie przypisywane wartościom przez wybierającego. Zapytano młodzież o ich wybory, gdy istnieje możliwość wykorzystania stanowiska służbowego dla własnej korzyści, gdy należy płacić podatki, gdy spotyka się z zażywaniem narkotyków, gdy nadużywa się alkoholu, gdy ma miejsce współżycie seksualne poza małżeństwem, gdy dochodzi do przerywania ciąży, gdy znane są przypadki okradania rodziców.

Tabela 5. Wykorzystywanie stanowiska służbowego a stosunek do praktyk religijnych ${ }^{22}$

\begin{tabular}{|c|c|c|c|c|c|c|}
\hline \multirow{2}{*}{\multicolumn{2}{|c|}{$\begin{array}{l}\text { WYKORZYSTYWANIE } \\
\text { STANOWISKA SŁUŻBOWEGO }\end{array}$}} & \multicolumn{4}{|c|}{$\begin{array}{c}\text { STOSUNEK } \\
\text { DO PRAKTYK RELIGIJNYCH* }\end{array}$} & \multirow{3}{*}{\begin{tabular}{|l} 
OGÓEEM \\
256 \\
\end{tabular}} \\
\hline & & & \multirow{2}{*}{2} & \multirow{2}{*}{3} & \multirow{2}{*}{4} & \\
\hline & Liczebność & & & & & \\
\hline $\begin{array}{l}\text { 1. Całkowicle nie- } \\
\text { usprawiedliwione }\end{array}$ & $\begin{array}{l}\text { \% z stosunek do praktyk } \\
\text { religijnych }\end{array}$ & $33,7 \%$ & $31,0 \%$ & $25,0 \%$ & $26,1 \%$ & $29,6 \%$ \\
\hline \multirow{2}{*}{$\begin{array}{l}\text { 2. Częściowo nie- } \\
\text { usprawiedliwione }\end{array}$} & Liczebność & 32 & 50 & 33 & 14 & 129 \\
\hline & $\begin{array}{l}\% \text { z stosunek do praktyk } \\
\text { religijnych }\end{array}$ & $12,5 \%$ & $18,1 \%$ & $13,8 \%$ & $15,2 \%$ & $14,9 \%$ \\
\hline \multirow{2}{*}{$\begin{array}{l}\text { 3. W małym stopniu } \\
\text { nieusprawiedliwione }\end{array}$} & Liczebność & 36 & 36 & 30 & 6 & 108 \\
\hline & $\begin{array}{l}\text { \% z stosunek do praktyk } \\
\text { religijnych }\end{array}$ & $14,1 \%$ & $13,0 \%$ & $12,5 \%$ & $6,5 \%$ & $12,5 \%$ \\
\hline \multirow[b]{2}{*}{ 4. Obojętne } & Liczebność & 48 & 46 & 47 & 21 & 162 \\
\hline & $\begin{array}{l}\text { \% z stosunek do praktyk } \\
\text { religijnych }\end{array}$ & $18,8 \%$ & $16,6 \%$ & $19,6 \%$ & $22,8 \%$ & $18,8 \%$ \\
\hline
\end{tabular}

${ }_{21}$ Por. K. Skoczylas, Wartości religijno-moralne..., dz. cyt., s. 187-211.

22 K. Skoczylas, Wartości religijno-moralne..., dz. cyt., s. 246. 


\begin{tabular}{|c|c|c|c|c|c|c|}
\hline \multirow{2}{*}{\multicolumn{2}{|c|}{$\begin{array}{l}\text { WYKORZYSTYWANIE } \\
\text { STANOWISKA SŁUŻBOWEGO }\end{array}$}} & \multicolumn{4}{|c|}{$\begin{array}{c}\text { STOSUNEK } \\
\text { DO PRAKTYK RELIGIJNYCH* }\end{array}$} & \multirow{3}{*}{$\begin{array}{c}\text { OGÓŁEM } \\
106 \\
\end{array}$} \\
\hline & & \multirow{2}{*}{$\frac{1}{33}$} & \multirow{2}{*}{2} & \multirow{2}{*}{$\begin{array}{c}3 \\
35 \\
\end{array}$} & \multirow{2}{*}{9} & \\
\hline & Liczebność & & & & & \\
\hline usprawiedliwione & $\begin{array}{l}\% \text { z stosunek do praktyk } \\
\text { religijnych }\end{array}$ & $12,9 \%$ & $10,5 \%$ & $14,6 \%$ & $9,8 \%$ & $12,3 \%$ \\
\hline \multirow{2}{*}{$\begin{array}{l}\text { 6. Czesściowo uspra- } \\
\text { wiedliwione }\end{array}$} & Liczebność & 4 & 10 & 9 & 8 & 31 \\
\hline & $\begin{array}{l}\% \text { z stosunek do praktyk } \\
\text { religijnych }\end{array}$ & $1,6 \%$ & $3,6 \%$ & $3,8 \%$ & $8,7 \%$ & $3,6 \%$ \\
\hline \multirow{2}{*}{$\begin{array}{l}\text { 7. Całkowicie uspra- } \\
\text { wiedliwione }\end{array}$} & Liczebność & 8 & 11 & 20 & 10 & 49 \\
\hline & $\begin{array}{l}\% \text { z stosunek do praktyk } \\
\text { religijnych }\end{array}$ & $3,1 \%$ & $4,0 \%$ & $8,3 \%$ & $10,9 \%$ & $5,7 \%$ \\
\hline \multirow[b]{2}{*}{ 8. Brak danych } & Liczebność & 8 & 9 & 6 & 0 & 23 \\
\hline & $\begin{array}{l}\% \text { z stosunek do praktyk } \\
\text { religijnych }\end{array}$ & $3,1 \%$ & $3,2 \%$ & $2,5 \%$ & $0,0 \%$ & $2,7 \%$ \\
\hline \multirow{2}{*}{$\begin{array}{l}\text { Ogółem } \\
\text { \% z stosunek do prak- } \\
\text { tyk religijnych }\end{array}$} & Liczebność & 255 & 277 & 240 & 92 & 864 \\
\hline & $100,0 \%$ & $100,0 \%$ & $100,0 \%$ & $100,0 \%$ & $100,0 \%$ & $100,0 \%$ \\
\hline
\end{tabular}

$\mathrm{Chi}^{2}=38,235 \quad \mathrm{df}=21 \quad \mathrm{p}=0,012 \quad$ V Kramera $=0,121 \quad \mathrm{p}=0,012$

*Uwaga: Cyfry w kolumnie stosunek do praktyk religijnych oznaczają: 1 - praktykuję systematycznie; 2 - praktykuję niesystematycznie; 3 - praktykuję rzadko; 4 - nie praktykuję wcale.

Z tabeli 5 wynika, że osoby praktykujące systematycznie (60,3 proc.) częściej niż osoby niepraktykujące $(53,8$ proc.) wykorzystywanie stanowiska służbowego dla celów prywatnych określają jako złe. Zarazem osoby niepraktykujące (29,4 proc.) częściej niż praktykujące systematycznie (17,6 proc.) to zachowanie określają jako moralnie dobre. Stosunek do praktyk religijnych oceny tego zachowania różnicuje w sposób statystycznie bardzo istotny. Widać zarazem erozję ocen moralnych nawet wśród osób związanych z wiarą przez jej praktykowanie. 
Tabela 6. Oszustwa podatkowe a stosunek do praktyk religijnych ${ }^{23}$

\begin{tabular}{|c|c|c|c|c|c|c|}
\hline \multicolumn{2}{|c|}{ OSZUSTWA PODATKOWE } & \multicolumn{4}{|c|}{$\begin{array}{c}\text { STOSUNEK } \\
\text { DO PRAKTYK RELIGIJNYCH* }\end{array}$} & \multirow{3}{*}{$\begin{array}{c}\text { OGÓŁEM } \\
455 \\
\end{array}$} \\
\hline & & \multirow{2}{*}{1} & \multirow{2}{*}{2} & \multirow{2}{*}{$\frac{3}{120}$} & \multirow{2}{*}{4} & \\
\hline & Liczebność & & & & & \\
\hline $\begin{array}{l}\text { 1. Całkowicie nie- } \\
\text { usprawiedliwione }\end{array}$ & $\begin{array}{l}\text { \% z stosunek do praktyk } \\
\text { religijnych }\end{array}$ & $52,9 \%$ & $57,8 \%$ & $50,0 \%$ & $43,5 \%$ & $52,7 \%$ \\
\hline \multirow{2}{*}{$\begin{array}{l}\text { 2. Częściowo nie- } \\
\text { usprawiedliwione }\end{array}$} & Liczebność & 45 & 37 & 26 & 6 & 114 \\
\hline & $\begin{array}{l}\% \text { z stosunek do praktyk } \\
\text { religijnych }\end{array}$ & $17,6 \%$ & $13,4 \%$ & $10,8 \%$ & $6,5 \%$ & $13,2 \%$ \\
\hline \multirow{2}{*}{$\begin{array}{l}\text { 3. W małym stopniu } \\
\text { nieusprawiedliwione }\end{array}$} & Liczebność & 27 & 33 & 28 & 11 & 99 \\
\hline & $\begin{array}{l}\% \text { z stosunek do praktyk } \\
\text { religijnych }\end{array}$ & $10,6 \%$ & $11,9 \%$ & $11,7 \%$ & $12,0 \%$ & $11,5 \%$ \\
\hline \multirow[b]{2}{*}{ 4. Obojętne } & Liczebność & 25 & 25 & 39 & 17 & 106 \\
\hline & $\begin{array}{l}\text { \% z stosunek do praktyk } \\
\text { religijnych }\end{array}$ & $9,8 \%$ & $9,0 \%$ & $16,3 \%$ & $18,5 \%$ & $12,3 \%$ \\
\hline \multirow[b]{2}{*}{$\begin{array}{l}\text { 5. W małym stopniu } \\
\text { usprawiedliwione }\end{array}$} & Liczebność & 3 & 5 & 4 & 7 & 19 \\
\hline & $\begin{array}{l}\text { \% z stosunek do praktyk } \\
\text { religijnych }\end{array}$ & $1,2 \%$ & $1,8 \%$ & $1,7 \%$ & $7,6 \%$ & $2,2 \%$ \\
\hline \multirow{2}{*}{$\begin{array}{l}\text { 6. Częściowo uspra- } \\
\text { wiedliwione }\end{array}$} & Liczebność & 5 & 4 & 5 & 3 & 17 \\
\hline & $\begin{array}{l}\% \text { z stosunek do praktyk } \\
\text { religijnych }\end{array}$ & $2,0 \%$ & $1,4 \%$ & $2,1 \%$ & $3,3 \%$ & $2,0 \%$ \\
\hline \multirow{2}{*}{$\begin{array}{l}\text { 7. Całkowicie uspra- } \\
\text { wiedliwione }\end{array}$} & Liczebność & 7 & 4 & 12 & 8 & 31 \\
\hline & $\begin{array}{l}\% \text { z stosunek do praktyk } \\
\text { religijnych }\end{array}$ & $2,7 \%$ & $1,4 \%$ & $5,0 \%$ & $8,7 \%$ & $3,6 \%$ \\
\hline \multirow[b]{2}{*}{ 8. Brak danych } & Liczebność & 8 & 9 & 6 & 0 & 23 \\
\hline & $\begin{array}{l}\text { \% z stosunek do praktyk } \\
\text { religijnych }\end{array}$ & $3,1 \%$ & $3,2 \%$ & $2,5 \%$ & $0,0 \%$ & $2,7 \%$ \\
\hline \multirow{2}{*}{$\begin{array}{l}\text { Ogółem } \\
\text { \% z stosunek do prak- } \\
\text { tyk religijnych }\end{array}$} & Liczebność & 255 & 277 & 240 & 92 & 864 \\
\hline & $100,0 \%$ & $100,0 \%$ & $100,0 \%$ & $100,0 \%$ & $100,0 \%$ & $100,0 \%$ \\
\hline
\end{tabular}

$\mathrm{Chi}^{2}=51,270 \quad \mathrm{df}=21 \quad \mathrm{p}=0,000 \quad$ V Kramera $=0,141 \quad \mathrm{p}=0,000$

*Uwaga: Cyfry w kolumnie stosunek do praktyk religijnych oznaczają: 1 - praktykuję systematycznie; 2 - praktykuję niesystematycznie; 3 - praktykuję rzadko; 4 - nie praktykuję wcale.

${ }^{23}$ K. Skoczylas, Wartości religijno-moralne..., dz. cyt., s. 248-249. 
Tabela 6 przedstawia stosunek do oszustw podatkowych ze względu na stosunek do wiary. Osoby praktykujące systematycznie (81,1 proc.) częściej niż niepraktykujące (62 proc.) oceniają to zachowanie jako moralnie niedopuszczalne. Większy odsetek niepraktykujących ocenia je jako obojętne (18,5 proc.), a jako moralnie dobre - 19,6 proc. Stosunek do praktyk różnicuje oceny oszustw podatkowych w sposób statystycznie bardzo istotny.

Tabela 7. Zażywanie narkotyków a stosunek do praktyk religijnych ${ }^{24}$

\begin{tabular}{|c|c|c|c|c|c|c|}
\hline \multirow{2}{*}{\multicolumn{2}{|c|}{ OCENY ZAŻYWANIA NARKOTYKÓW }} & \multicolumn{4}{|c|}{$\begin{array}{c}\text { STOSUNEK } \\
\text { DO PRAKTYK RELIGIJNYCH* }\end{array}$} & \multirow{3}{*}{\begin{tabular}{|c} 
OGÓŁEM \\
426
\end{tabular}} \\
\hline & & \multirow{2}{*}{$\frac{1}{149}$} & \multirow{2}{*}{$\frac{2}{138}$} & \multirow{2}{*}{$\frac{3}{105}$} & \multirow{2}{*}{$\begin{array}{l}4 \\
34 \\
\end{array}$} & \\
\hline 1 Catkowicio nis- & Liczebność & & & & & \\
\hline usprawiedliwione & $\begin{array}{l}\% \text { z stosunek do praktyk } \\
\text { religijnych }\end{array}$ & $58,4 \%$ & $49,8 \%$ & $43,8 \%$ & $37,0 \%$ & $49,3 \%$ \\
\hline \multirow{2}{*}{$\begin{array}{l}\text { 2. Częściowo nie- } \\
\text { usprawiedliwione }\end{array}$} & Liczebność & 30 & 38 & 31 & 8 & 107 \\
\hline & $\begin{array}{l}\% \text { z stosunek do praktyk } \\
\text { religijnych }\end{array}$ & $11,8 \%$ & $13,7 \%$ & $12,9 \%$ & $8,7 \%$ & $12,4 \%$ \\
\hline \multirow{2}{*}{$\begin{array}{l}\text { 3. W małym stopniu } \\
\text { nieusprawiedliwione }\end{array}$} & Liczebność & 22 & 24 & 13 & 6 & 65 \\
\hline & $\begin{array}{l}\text { \% z stosunek do praktyk } \\
\text { religijnych }\end{array}$ & $8,6 \%$ & $8,7 \%$ & $5,4 \%$ & $6,5 \%$ & $7,5 \%$ \\
\hline \multirow[b]{2}{*}{ 4. Obojętne } & Liczebność & 30 & 45 & 49 & 23 & 147 \\
\hline & $\begin{array}{l}\% \text { z stosunek do praktyk } \\
\text { religijnych }\end{array}$ & $11,8 \%$ & $16,2 \%$ & $20,4 \%$ & $25,0 \%$ & $17,0 \%$ \\
\hline \multirow{2}{*}{$\begin{array}{l}\text { 5. W małym stopniu } \\
\text { usprawiedliwione }\end{array}$} & Liczebność & 6 & 12 & 9 & 4 & 31 \\
\hline & $\begin{array}{l}\text { \% z stosunek do praktyk } \\
\text { religijnych }\end{array}$ & $2,4 \%$ & $4,3 \%$ & $3,8 \%$ & $4,3 \%$ & $3,6 \%$ \\
\hline \multirow{2}{*}{$\begin{array}{l}\text { 6. Częściowo uspra- } \\
\text { wiedliwione }\end{array}$} & Liczebność & 2 & 9 & 8 & 9 & 28 \\
\hline & $\begin{array}{l}\text { \% z stosunek do praktyk } \\
\text { religijnych }\end{array}$ & $0,8 \%$ & $3,2 \%$ & $3,3 \%$ & $9,8 \%$ & $3,2 \%$ \\
\hline \multirow{2}{*}{$\begin{array}{l}\text { 7. Całkowicie uspra- } \\
\text { wiedliwione }\end{array}$} & Liczebność & 8 & 4 & 15 & 7 & 34 \\
\hline & $\begin{array}{l}\text { \% z stosunek do praktyk } \\
\text { religijnych }\end{array}$ & $3,1 \%$ & $1,4 \%$ & $6,3 \%$ & $7,6 \%$ & $3,9 \%$ \\
\hline
\end{tabular}

${ }^{24}$ K. Skoczylas, Wartości religijno-moralne..., dz. cyt., s. 253-254. 


\begin{tabular}{|l|l|c|c|c|c|c|}
\hline \multicolumn{2}{|c|}{ OCENY ZAŻYWANIA NARKOTYKÓW } & \multicolumn{4}{c|}{$\begin{array}{c}\text { STOSUNEK } \\
\text { DO PRAKTYK RELIGIJNYCH* }\end{array}$} & \multirow{2}{*}{ OGÓłEM } \\
\cline { 2 - 7 } & & 1 & 2 & 3 & 4 & \\
\hline \multirow{2}{*}{$\begin{array}{l}\text { 8. Brak danych } \\
\text { Liczebność }\end{array}$} & $\begin{array}{l}\text { \% z stosunek do praktyk } \\
\text { religijnych }\end{array}$ & $3,1 \%$ & $2,5 \%$ & $4,2 \%$ & $1,1 \%$ & $3,0 \%$ \\
\hline $\begin{array}{l}\text { Ogółem } \\
\text { \% z stosunek do } \\
\text { praktyk religijnych }\end{array}$ & Liczebność & 255 & 277 & 240 & 92 & 864 \\
\cline { 2 - 7 } & $100,0 \%$ & $100,0 \%$ & $100,0 \%$ & $100,0 \%$ & $100,0 \%$ & $100,0 \%$ \\
\hline
\end{tabular}

$\mathrm{Chi}^{2}=54,162 \quad \mathrm{df}=21 \quad \mathrm{p}=0,000 \quad$ V Kramera $=0,145 \quad \mathrm{p}=0,000$

*Uwaga: Cyfry w kolumnie stosunek do praktyk religijnych oznaczają: 1 - praktykuję systematycznie; 2 - praktykuję niesystematycznie; 3 - praktykuję rzadko; 4 - nie praktykuję wcale.

Kolejna tabela (7) przedstawia oceny zażywania narkotyków ze względu na stosunek do praktyk religijnych. Praktykujący systematycznie (78,8 proc.) częściej niż niepraktykujący (52,2 proc.) oceniają to jako zachowanie moralnie złe. Zażywanie narkotyków jest traktowane jako moralnie usprawiedliwione przez 6,3 proc. praktykujących systematycznie oraz 21 proc. niepraktykujących. Zarazem wśród niepraktykujących najwyższy jest odsetek (25 proc.) uznających je za działanie moralnie obojętne. Stosunek do praktyk różnicuje oceny zażywania narkotyków w sposób statystycznie bardzo istotny.

Tabela 8. Ocena nadużywania alkoholu a stosunek do praktyk religijnych ${ }^{25}$

\begin{tabular}{|c|c|c|c|c|c|c|}
\hline \multirow{2}{*}{\multicolumn{2}{|c|}{ OCENA NADUŻYWANIA ALKOHOLU }} & \multicolumn{4}{|c|}{$\begin{array}{c}\text { STOSUNEK } \\
\text { DO PRAKTYK RELIGIJNYCH* }\end{array}$} & \multirow{2}{*}{$\begin{array}{l}\text { OGÓ- } \\
\text { ŁEM }\end{array}$} \\
\hline & & 1 & 2 & 3 & 4 & \\
\hline \multirow{2}{*}{$\begin{array}{l}\text { 1. Całkowicie nieuspra- } \\
\text { wiedliwione }\end{array}$} & Liczebność & 86 & 63 & 49 & 25 & 223 \\
\hline & $\begin{array}{l}\text { \% z stosunek do praktyk } \\
\text { religijnych }\end{array}$ & $33,7 \%$ & $22,7 \%$ & $20,4 \%$ & $27,2 \%$ & $25,8 \%$ \\
\hline
\end{tabular}

25 K. Skoczylas, Wartości religijno-moralne..., dz. cyt., s. 264. 


\begin{tabular}{|c|c|c|c|c|c|c|}
\hline \multirow{2}{*}{\multicolumn{2}{|c|}{ OCENA NADUŻYWANIA ALKOHOLU }} & \multicolumn{4}{|c|}{$\begin{array}{c}\text { STOSUNEK } \\
\text { DO PRAKTYK RELIGIJNYCH* }\end{array}$} & \multirow{3}{*}{$\begin{array}{l}\text { OGÓ- } \\
\text { ŁEM } \\
126 \\
\end{array}$} \\
\hline & & \multirow{2}{*}{\begin{tabular}{c|c}
1 \\
47
\end{tabular}} & \multirow{2}{*}{2} & & \multirow{2}{*}{$\begin{array}{ll} & 4 \\
9 & \\
\end{array}$} & \\
\hline & Liczebność & & & & & \\
\hline wiedliwione & $\begin{array}{l}\% \text { z stosunek do praktyk } \\
\text { religijnych }\end{array}$ & $18,4 \%$ & $14,8 \%$ & $12,1 \%$ & $9,8 \%$ & $14,6 \%$ \\
\hline \multirow{2}{*}{$\begin{array}{l}\text { 3. W małym stopniu nie- } \\
\text { usprawiedliwione }\end{array}$} & Liczebność & 36 & 39 & 29 & 15 & 119 \\
\hline & $\begin{array}{l}\% \text { z stosunek do praktyk } \\
\text { religijnych }\end{array}$ & $14,1 \%$ & $14,1 \%$ & $12,1 \%$ & $16,3 \%$ & $13,8 \%$ \\
\hline \multirow[b]{2}{*}{ 4. Obojętne } & Liczebność & 44 & 70 & 63 & 17 & 194 \\
\hline & $\begin{array}{l}\% \text { z stosunek do praktyk } \\
\text { religijnych }\end{array}$ & $17,3 \%$ & $25,3 \%$ & $26,3 \%$ & $18,5 \%$ & $22,5 \%$ \\
\hline \multirow{2}{*}{$\begin{array}{l}\text { 5. W małym stopniu } \\
\text { usprawiedliwione }\end{array}$} & Liczebność & 15 & 23 & 21 & 4 & 63 \\
\hline & $\begin{array}{l}\text { \% z stosunek do praktyk } \\
\text { religijnych }\end{array}$ & $5,9 \%$ & $8,3 \%$ & $8,8 \%$ & $4,3 \%$ & $7,3 \%$ \\
\hline \multirow{2}{*}{$\begin{array}{l}\text { 6. Częściowo usprawied- } \\
\text { liwione }\end{array}$} & Liczebność & 4 & 16 & 11 & 12 & 43 \\
\hline & $\begin{array}{l}\% \text { z stosunek do praktyk } \\
\text { religijnych }\end{array}$ & $1,6 \%$ & $5,8 \%$ & $4,6 \%$ & $13,0 \%$ & $5,0 \%$ \\
\hline \multirow{2}{*}{$\begin{array}{l}\text { 7. Całkowicie usprawied- } \\
\text { liwione }\end{array}$} & Liczebność & 15 & 15 & 28 & 7 & 65 \\
\hline & $\begin{array}{l}\text { \% z stosunek do praktyk } \\
\text { religijnych }\end{array}$ & $5,9 \%$ & $5,4 \%$ & $11,7 \%$ & $7,6 \%$ & $7,5 \%$ \\
\hline \multirow[b]{2}{*}{ 8. Brak danych } & Liczebność & 8 & 10 & 10 & 3 & 31 \\
\hline & $\begin{array}{l}\% \text { z stosunek do praktyk } \\
\text { religijnych }\end{array}$ & $3,1 \%$ & $3,6 \%$ & $4,2 \%$ & $3,3 \%$ & $3,6 \%$ \\
\hline \multirow{2}{*}{$\begin{array}{l}\text { Ogółem } \\
\text { \% z stosunek do praktyk } \\
\text { religijnych }\end{array}$} & Liczebność & 255 & 277 & 240 & 92 & 864 \\
\hline & $100,0 \%$ & $100,0 \%$ & $100,0 \%$ & $100,0 \%$ & $100,0 \%$ & $100,0 \%$ \\
\hline
\end{tabular}

$\mathrm{Chi}^{2}=51,964 \quad \mathrm{df}=21 \quad \mathrm{p}=0,000 \quad$ V Kramera $=0,142 \quad \mathrm{p}=0,000$

*Uwaga: Cyfry w kolumnie stosunek do praktyk religijnych oznaczają: 1 - praktykuję systematycznie; 2 - praktykuję niesystematycznie; 3 - praktykuję rzadko; 4 - nie praktykuję wcale.

Nadużywanie alkoholu jest nieco częściej potępiane przez praktykujących religijnie (68,2 proc.) niż przez niepraktykujących wcale (53,3 proc.). Stosunek do praktyk różnicuje w sposób statystycznie bardzo istotny oceny nadużywania alkoholu.

Postawy młodzieży wobec alkoholu są zróżnicowane. Większość (54 proc.) potępia nadużywanie alkoholu, dla niemal co piątego upijanie się jest obojętne. Natomiast 21,7 proc. uznaje takie postepowanie 
za moralnie dobre. W tym młodym pokoleniu jest już stosunkowo duże przyzwolenie na picie alkoholu.

Wiara wymaga, aby przestrzegać przykazania „nie kradnij” także w odniesieniu do kręgu najbliższej rodziny. Przejawem kradzieży jest wyjmowanie rodzicom pieniędzy z portfela bez ich wiedzy. Postawy młodych ludzi wobec takich zachowań przedstawia kolejna tabela.

Tabela 9. Wyjmowanie pieniędzy rodzicom a stosunek do praktyk religijnych ${ }^{26}$

\begin{tabular}{|c|c|c|c|c|c|c|}
\hline \multirow{2}{*}{\multicolumn{2}{|c|}{ WYJMOWANIE PIENIĘDZY RODZICOM }} & \multicolumn{4}{|c|}{$\begin{array}{c}\text { STOSUNEK } \\
\text { DO PRAKTYK RELIGIJNYCH* }\end{array}$} & \multirow{3}{*}{$\begin{array}{c}\text { OGÓŁEM } \\
319 \\
\end{array}$} \\
\hline & & \multirow{2}{*}{11} & \multirow{2}{*}{2} & \multirow{2}{*}{3} & \multirow{2}{*}{4} & \\
\hline & Liczebność & & & & & \\
\hline usprawiedliwione & $\begin{array}{l}\% \text { z stosunek do praktyk } \\
\text { religijnych }\end{array}$ & $43,5 \%$ & $35,4 \%$ & $33,3 \%$ & $32,6 \%$ & $36,9 \%$ \\
\hline \multirow{2}{*}{$\begin{array}{l}\text { 2. Częściowo nie- } \\
\text { usprawiedliwione }\end{array}$} & Liczebność & 37 & 38 & 41 & 14 & 130 \\
\hline & $\begin{array}{l}\text { \% z stosunek do praktyk } \\
\text { religijnych }\end{array}$ & $14,5 \%$ & $13,7 \%$ & $17,1 \%$ & $15,2 \%$ & $15,0 \%$ \\
\hline \multirow{2}{*}{$\begin{array}{l}\text { 3. W małym stop- } \\
\text { niu nieusprawiedli- } \\
\text { wione }\end{array}$} & Liczebność & 44 & 53 & 38 & 12 & 147 \\
\hline & $\begin{array}{l}\% \text { z stosunek do praktyk } \\
\text { religijnych }\end{array}$ & $17,3 \%$ & $19,1 \%$ & $15,8 \%$ & $13,0 \%$ & $17,0 \%$ \\
\hline \multirow[b]{2}{*}{ 4. Oobojętne } & Liczebność & 26 & 55 & 46 & 17 & 144 \\
\hline & $\begin{array}{l}\% \text { z stosunek do praktyk } \\
\text { religijnych }\end{array}$ & $10,2 \%$ & $19,9 \%$ & $19,2 \%$ & $18,5 \%$ & $16,7 \%$ \\
\hline \multirow[b]{2}{*}{$\begin{array}{l}\text { 5. W małym stopniu } \\
\text { usprawiedliwione }\end{array}$} & Liczebność & 14 & 14 & 12 & 6 & 46 \\
\hline & $\begin{array}{l}\text { \% z stosunek do praktyk } \\
\text { religijnych }\end{array}$ & $5,5 \%$ & $5,1 \%$ & $5,0 \%$ & $6,5 \%$ & $5,3 \%$ \\
\hline \multirow{2}{*}{$\begin{array}{l}\text { 6. Częściowo uspra- } \\
\text { wiedliwione }\end{array}$} & Liczebność & 5 & 8 & 6 & 6 & 25 \\
\hline & $\begin{array}{l}\text { \% z stosunek do praktyk } \\
\text { religijnych }\end{array}$ & $2,0 \%$ & $2,9 \%$ & $2,5 \%$ & $6,5 \%$ & $2,9 \%$ \\
\hline \multirow[b]{2}{*}{$\begin{array}{l}\text { 7. Całkowicie uspra- } \\
\text { wiedliwione }\end{array}$} & Liczebność & 10 & 6 & 10 & 6 & 32 \\
\hline & $\begin{array}{l}\% \text { z stosunek do praktyk } \\
\text { religijnych }\end{array}$ & $3,9 \%$ & $2,2 \%$ & $4,2 \%$ & $6,5 \%$ & $3,7 \%$ \\
\hline
\end{tabular}

${ }^{26}$ K. Skoczylas, Wartości religijno-moralne..., dz. cyt., s. 269. 


\begin{tabular}{|c|c|c|c|c|c|c|}
\hline \multirow{2}{*}{\multicolumn{2}{|c|}{ WYJMOWANIE PIENIĘDZY RODZICOM }} & \multicolumn{4}{|c|}{$\begin{array}{c}\text { STOSUNEK } \\
\text { DO PRAKTYK RELIGIJNYCH* }\end{array}$} & \multirow{3}{*}{$\begin{array}{c}\text { OGÓłEM } \\
21 \\
\end{array}$} \\
\hline & & 1 & 2 & 3 & 4 & \\
\hline \multirow[b]{2}{*}{ 8. Brak danych } & Liczebność & 8 & 5 & 7 & 1 & \\
\hline & $\begin{array}{l}\text { \% z stosunek do praktyk } \\
\text { religijnych }\end{array}$ & $3,1 \%$ & $1,8 \%$ & $2,9 \%$ & $1,1 \%$ & $2,4 \%$ \\
\hline \multirow{2}{*}{$\begin{array}{l}\text { Ogółem } \\
\text { \% z stosunek } \\
\text { do praktyk } \\
\text { religijnych }\end{array}$} & Liczebność & 255 & 277 & 240 & 92 & 864 \\
\hline & $100,0 \%$ & $100,0 \%$ & $100,0 \%$ & $100,0 \%$ & $100,0 \%$ & $100,0 \%$ \\
\hline
\end{tabular}

Chi $^{2}=27,724 \quad \mathrm{df}=21 \quad \mathrm{p}=0,148 \quad$ V Kramera $=0,103 \quad \mathrm{p}=0,148$

*Uwaga: Cyfry w kolumnie stosunek do praktyk religijnych oznaczają: 1 - praktykuję systematycznie; 2 - praktykuję niesystematycznie; 3 - praktykuję rzadko; 4 - nie praktykuję wcale.

Okradanie rodziców jest najczęściej potępiane, niezależnie od stosunku do praktyk religijnych. Ta zmienna nie różnicuje w sposób statystycznie istotny ocen okradania rodziców.

Tabela 10. Przedmałżeńskie stosunki seksualne a stosunek do praktyk religijnych ${ }^{27}$

\begin{tabular}{|c|c|c|c|c|c|c|}
\hline \multirow{2}{*}{\multicolumn{2}{|c|}{ PRZEDMAŁŻEŃSKIE STOSUNKI SEKSUALNE }} & \multicolumn{4}{|c|}{$\begin{array}{c}\text { STOSUNEK } \\
\text { DO PRAKTYK RELIGIJNYCH* }\end{array}$} & \multirow{3}{*}{$\begin{array}{c}\text { OGÓŁEM } \\
86 \\
\end{array}$} \\
\hline & & 1 & 2 & 3 & 4 & \\
\hline \multirow{2}{*}{$\begin{array}{l}\text { 1. Całkowicie nie- } \\
\text { usprawiedliwione }\end{array}$} & Liczebność & 46 & 18 & 9 & 13 & \\
\hline & $\begin{array}{l}\text { \% z stosunek do praktyk } \\
\text { religijnych }\end{array}$ & $18,0 \%$ & $6,5 \%$ & $3,8 \%$ & $14,3 \%$ & $10,0 \%$ \\
\hline \multirow{2}{*}{$\begin{array}{l}\text { 2. Częściowo nie- } \\
\text { usprawiedliwione }\end{array}$} & Liczebność & 24 & 17 & 7 & 1 & 49 \\
\hline & $\begin{array}{l}\% \text { z stosunek do praktyk } \\
\text { religijnych }\end{array}$ & $9,4 \%$ & $6,1 \%$ & $2,9 \%$ & $1,1 \%$ & $5,7 \%$ \\
\hline \multirow{2}{*}{$\begin{array}{l}\text { 3. W małym stop- } \\
\text { niu nieusprawiedli- } \\
\text { wione }\end{array}$} & Liczebność & 29 & 12 & 8 & 1 & 50 \\
\hline & $\begin{array}{l}\text { \% z stosunek do praktyk } \\
\text { religijnych }\end{array}$ & $11,4 \%$ & $4,3 \%$ & $3,3 \%$ & $1,1 \%$ & $5,8 \%$ \\
\hline
\end{tabular}

27 K. Skoczylas, Wartości religijno-moralne..., dz. cyt., s. 271-272. 


\begin{tabular}{|c|c|c|c|c|c|c|}
\hline \multirow{2}{*}{\multicolumn{2}{|c|}{ PRZEDMAŁŻEŃSKIE STOSUNKI SEKSUALNE }} & \multicolumn{4}{|c|}{$\begin{array}{c}\text { STOSUNEK } \\
\text { DO PRAKTYK RELIGIJNYCH* }\end{array}$} & \multirow{3}{*}{$\begin{array}{c}\text { OGÓŁEM } \\
235 \\
\end{array}$} \\
\hline & & \multirow{2}{*}{\begin{tabular}{c|}
1 \\
73 \\
\end{tabular}} & \multirow{2}{*}{$\frac{2}{92}$} & \multirow{2}{*}{$\frac{3}{53}$} & \multirow{2}{*}{4} & \\
\hline & Liczebność & & & & & \\
\hline 4. Obojętne & $\begin{array}{l}\% \text { z stosunek do praktyk } \\
\text { religijnych }\end{array}$ & $28,6 \%$ & $33,2 \%$ & $22,1 \%$ & $18,7 \%$ & $27,2 \%$ \\
\hline \multirow{2}{*}{$\begin{array}{l}\text { 5. W małym stopniu } \\
\text { usprawiedliwione }\end{array}$} & Liczebność & 18 & 24 & 17 & 4 & 63 \\
\hline & $\begin{array}{l}\text { \% z stosunek do praktyk } \\
\text { religijnych }\end{array}$ & $7,1 \%$ & $8,7 \%$ & $7,1 \%$ & $4,4 \%$ & $7,3 \%$ \\
\hline \multirow{2}{*}{$\begin{array}{l}\text { 6. Częściowo uspra- } \\
\text { wiedliwione }\end{array}$} & Liczebność & 18 & 31 & 27 & 3 & 79 \\
\hline & $\begin{array}{l}\text { \% z stosunek do praktyk } \\
\text { religijnych }\end{array}$ & $7,1 \%$ & $11,2 \%$ & $11,3 \%$ & $3,3 \%$ & $9,2 \%$ \\
\hline \multirow{2}{*}{$\begin{array}{l}\text { 7. Całkowicie uspra- } \\
\text { wiedliwione }\end{array}$} & Liczebność & 40 & 72 & 111 & 50 & 273 \\
\hline & $\begin{array}{l}\text { \% z stosunek do praktyk } \\
\text { religijnych }\end{array}$ & $15,7 \%$ & $26,0 \%$ & $46,3 \%$ & $54,9 \%$ & $31,6 \%$ \\
\hline \multirow[b]{2}{*}{ 8. Brak danych } & Liczebność & 7 & 11 & 8 & 2 & 28 \\
\hline & $\begin{array}{l}\% \text { z stosunek do praktyk } \\
\text { religijnych }\end{array}$ & $2,7 \%$ & $4,0 \%$ & $3,3 \%$ & $2,2 \%$ & $3,2 \%$ \\
\hline \multirow{2}{*}{$\begin{array}{l}\text { Ogółem } \\
\text { \% z stosunek } \\
\text { do praktyk } \\
\text { religijnych }\end{array}$} & Liczebność & 255 & 277 & 240 & 91 & 863 \\
\hline & $100,0 \%$ & $100,0 \%$ & $100,0 \%$ & $100,0 \%$ & $100,0 \%$ & $100,0 \%$ \\
\hline
\end{tabular}

$\mathrm{Chi}^{2}=138,190 \quad \mathrm{df}=21 \quad \mathrm{p}=0,000 \quad$ V Kramera $=0,231 \quad \mathrm{p}=0,000$

*Uwaga: Cyfry w kolumnie stosunek do praktyk religijnych oznaczają: 1 - praktykuję systematycznie; 2 - praktykuję niesystematycznie; 3 - praktykuję rzadko; 4 - nie praktykuję wcale.

Osoby praktykujące systematycznie w 38,8 proc. oceniają negatywnie przedmałżeńskie stosunki seksualne, a w 29,9 proc. oceniają je jako działanie moralnie dobre. Osoby praktykujące niesystematycznie oceniają te stosunki w 16,9 proc. jako moralnie złe, a zdecydowanie częściej (45,8 proc.) w tej grupie traktuje się je jako moralnie dobre. Praktykujący rzadko traktują je w 10 proc. jako moralnie złe, a 64,7 proc. jako moralnie dobre. Niepraktykujący wcale w 16,5 proc. oceniają je jako złe, a w 61,6 proc. jako moralnie dobre. Im bardziej luźny stosunek do praktyk religijnych, tym wyższy odsetek osób traktujących te zachowania jako moralnie dobre. Stosunek do praktyk różnicuje oceny tych zachowań w sposób statystycznie bardzo istotny. 
Wskaźnikiem przywiązania do nauczania Kościoła jest respektowanie jego nauczania w odniesieniu do moralności seksualnej. Wskaźnikiem tego stosunku jest między innymi ocena przedmałżeńskich stosunków seksualnych. Poglądy młodych prezentuje tabela 14 .

W ocenie tego zachowania oceny młodych w większości nie zgadzają się z ocenami moralności katolickiej. Młodzież w większości (54 proc.) ocenia takie zachowanie jako moralnie dobre, 22,9 proc. nie łączy z nim ocen moralnych i traktuje je jako obojętne. Natomiast 20 proc., czyli co piąty badany, takie zachowanie potępia. Proces odejścia od respektowania norm moralnych w tym zakresie jest daleko bardziej posunięty w mieście niż na wsi. Młodzieży wiejskiej trakującej takie zachowanie jako dobre jest 45,7 proc., a potępiającej jest 22,8 proc. Trzeba jednak zauważyć, że we wszystkich środowiskach przeważa tendencja do traktowania tego zachowania jako moralnie usprawiedliwionego.

Przejawem odrzucenia przykazania „Nie zabijaj” jest samobójstwo. Młodzież poproszono o ocenę samobójstwa. Przedstawia to kolejna tabela nr 11 .

Tabela 11. Oceny samobójstwa a stosunek do praktyk religijnych ${ }^{28}$

\begin{tabular}{|c|c|c|c|c|c|c|}
\hline \multirow{2}{*}{\multicolumn{2}{|c|}{ OCENY SAMOBÓJSTWA }} & \multicolumn{4}{|c|}{$\begin{array}{c}\text { STOSUNEK } \\
\text { DO PRAKTYK RELIGIJNYCH* }\end{array}$} & \multirow[t]{2}{*}{ OGÓŁEM } \\
\hline & & 1 & 2 & 3 & 4 & \\
\hline \multirow{2}{*}{$\begin{array}{l}\text { 1. Całkowicie nie- } \\
\text { usprawiedliwione }\end{array}$} & Liczebność & 144 & 128 & 92 & 33 & 397 \\
\hline & $\begin{array}{l}\% \text { z stosunek do praktyk } \\
\text { religijnych }\end{array}$ & $56,5 \%$ & $46,2 \%$ & $38,3 \%$ & $35,9 \%$ & $45,9 \%$ \\
\hline \multirow{2}{*}{$\begin{array}{l}\text { 2. Częściowo nie- } \\
\text { usprawiedliwione }\end{array}$} & Liczebność & 26 & 23 & 22 & 9 & 80 \\
\hline & $\begin{array}{l}\% \text { z stosunek do praktyk } \\
\text { religijnych }\end{array}$ & $10,2 \%$ & $8,3 \%$ & $9,2 \%$ & $9,8 \%$ & $9,3 \%$ \\
\hline \multirow{2}{*}{$\begin{array}{l}\text { 3. W małym stop- } \\
\text { niu nieusprawiedli- } \\
\text { wione }\end{array}$} & Liczebność & 23 & 32 & 27 & 10 & 92 \\
\hline & $\begin{array}{l}\% \text { z stosunek do praktyk } \\
\text { religijnych }\end{array}$ & $9,0 \%$ & $11,6 \%$ & $11,3 \%$ & $10,9 \%$ & $10,6 \%$ \\
\hline
\end{tabular}

${ }^{28} \quad$ K. Skoczylas, Wartości religijno-moralne..., dz. cyt., s. 274. 


\begin{tabular}{|c|c|c|c|c|c|c|}
\hline \multicolumn{2}{|c|}{ OCENY SAMOBÓJSTWA } & \multicolumn{4}{|c|}{$\begin{array}{c}\text { STOSUNEK } \\
\text { DO PRAKTYK RELIGIJNYCH* }\end{array}$} & \multirow{3}{*}{$\begin{array}{c}\text { OGÓEEM } \\
144 \\
\end{array}$} \\
\hline & & \multirow{2}{*}{1} & \multirow{2}{*}{2} & \multirow{2}{*}{$\begin{array}{l}3 \\
48 \\
\end{array}$} & \multirow{2}{*}{$\begin{array}{c}4 \\
15 \\
\end{array}$} & \\
\hline & Liczebność & & & & & \\
\hline 4. Obojętne & $\begin{array}{l}\text { \% z stosunek do praktyk } \\
\text { religijnych }\end{array}$ & $12,2 \%$ & $18,1 \%$ & $20,0 \%$ & $16,3 \%$ & $16,7 \%$ \\
\hline \multirow{2}{*}{$\begin{array}{l}\text { 5. W małym stopniu } \\
\text { usprawiedliwione }\end{array}$} & Liczebność & 11 & 16 & 13 & 9 & 49 \\
\hline & $\begin{array}{l}\% \text { z stosunek do praktyk } \\
\text { religijnych }\end{array}$ & $4,3 \%$ & $5,8 \%$ & $5,4 \%$ & $9,8 \%$ & $5,7 \%$ \\
\hline \multirow{2}{*}{$\begin{array}{l}\text { 6. Częściowo uspra- } \\
\text { wiedliwione }\end{array}$} & Liczebność & 3 & 8 & 7 & 2 & 20 \\
\hline & $\begin{array}{l}\% \text { z stosunek do praktyk } \\
\text { religijnych }\end{array}$ & $1,2 \%$ & $2,9 \%$ & $2,9 \%$ & $2,2 \%$ & $2,3 \%$ \\
\hline \multirow{2}{*}{$\begin{array}{l}\text { 7. Całkowicie uspra- } \\
\text { wiedliwione }\end{array}$} & Liczebność & 6 & 6 & 19 & 13 & 44 \\
\hline & $\begin{array}{l}\% \text { z stosunek do praktyk } \\
\text { religijnych }\end{array}$ & $2,4 \%$ & $2,2 \%$ & $7,9 \%$ & $14,1 \%$ & $5,1 \%$ \\
\hline \multirow[b]{2}{*}{ 8. Brak danych } & Liczebność & 11 & 14 & 12 & 1 & 38 \\
\hline & $\begin{array}{l}\% \text { z stosunek do praktyk } \\
\text { religijnych }\end{array}$ & $4,3 \%$ & $5,1 \%$ & $5,0 \%$ & $1,1 \%$ & $4,4 \%$ \\
\hline \multirow{2}{*}{$\begin{array}{l}\text { Ogółem } \\
\text { \% z stosunek } \\
\text { do praktyk religij- } \\
\text { nych }\end{array}$} & Liczebność & 255 & 277 & 240 & 92 & 864 \\
\hline & $100,0 \%$ & $100,0 \%$ & $100,0 \%$ & $100,0 \%$ & $100,0 \%$ & $100,0 \%$ \\
\hline
\end{tabular}

\section{$\mathrm{Chi}^{2}=53,232 \quad \mathrm{df}=21 \quad \mathrm{p}=0,000 \quad$ V Kramera $=0,143 \quad \mathrm{p}=0,000$}

*Uwaga: Cyfry w kolumnie stosunek do praktyk religijnych oznaczają: 1 - praktykuję systematycznie; 2 - praktykuję niesystematycznie; 3 - praktykuję rzadko; 4 - nie praktykuję wcale.

Stosunek do praktyk ma znaczenie w ocenie samobójstwa (tabela 11). Osoby praktykujące systematycznie (75,7 proc.) potępiają je znacznie częściej niż osoby niepraktykujące wcale (56,6 proc.). Osoby niepraktykujące $(26,1$ proc.) trzykrotnie częściej niż praktykujące systematycznie (7,9 proc.) oceniają samobójstwo jako moralnie usprawiedliwione. Stosunek do praktyk różnicuje w sposób statystycznie bardzo istotny oceny samobójstwa.

Kościół uczy szacunku do życia ludzkiego. Papież Jan Paweł II podkreślił w adhortacji Familiaris consortio: „Kościół mocno wierzy, że życie 
ludzkie, nawet gdy jest słabe i cierpiące, jest wspaniałym darem dobroci Bożej” (FC 30). Podkreśla też, że człowiek ma prawo do życia od momentu poczęcia do naturalnej śmierci. Stąd zapytano młodzież katolicką, która spotyka się z nauczaniem Kościoła na ten temat, jak ocenia przerywanie ciąży. Jej oceny zebrane są w tabeli nr 12.

Tabela 12. Ocena przerywania ciąży a stosunek do praktyk religijnych ${ }^{29}$

\begin{tabular}{|c|c|c|c|c|c|c|}
\hline \multirow{2}{*}{\multicolumn{2}{|c|}{ OCENA PRZERYWANIA CIĄŻY }} & \multicolumn{4}{|c|}{$\begin{array}{c}\text { STOSUNEK } \\
\text { DO PRAKTYK RELIGIJNYCH* }\end{array}$} & \multirow{3}{*}{$\begin{array}{c}\text { OGÓŁEM } \\
74 \\
\end{array}$} \\
\hline & & \multirow{2}{*}{1} & \multirow{2}{*}{2} & \multirow{2}{*}{3} & \multirow{2}{*}{4} & \\
\hline & Liczebność & & & & & \\
\hline 1. Dozwolone & $\begin{array}{l}\text { \% z stosunek do praktyk } \\
\text { religijnych }\end{array}$ & $4,7 \%$ & $7,2 \%$ & $10,0 \%$ & $19,6 \%$ & $8,6 \%$ \\
\hline \multirow[b]{2}{*}{ 2. To zależy } & Liczebność & 68 & 101 & 76 & 41 & 286 \\
\hline & $\begin{array}{l}\text { \% z stosunek do praktyk } \\
\text { religijnych }\end{array}$ & $26,7 \%$ & $36,5 \%$ & $31,7 \%$ & $44,6 \%$ & $33,1 \%$ \\
\hline \multirow[b]{2}{*}{ 3. Niedozwolone } & Liczebność & 138 & 108 & 92 & 30 & 368 \\
\hline & $\begin{array}{l}\text { \% z stosunek do praktyk } \\
\text { religijnych }\end{array}$ & $54,1 \%$ & $39,0 \%$ & $38,3 \%$ & $32,6 \%$ & $42,6 \%$ \\
\hline \multirow{2}{*}{$\begin{array}{l}\text { 4. Nie umiem powie- } \\
\text { dzieć }\end{array}$} & Liczebność & 23 & 34 & 31 & 2 & 90 \\
\hline & $\begin{array}{l}\% \text { z stosunek do praktyk } \\
\text { religijnych }\end{array}$ & $9,0 \%$ & $12,3 \%$ & $12,9 \%$ & $2,2 \%$ & $10,4 \%$ \\
\hline \multirow[b]{2}{*}{ 5. Brak danych } & Liczebność & 14 & 14 & 17 & 1 & 46 \\
\hline & $\begin{array}{l}\% \text { z stosunek do praktyk } \\
\text { religijnych }\end{array}$ & $5,5 \%$ & $5,1 \%$ & $7,1 \%$ & $1,1 \%$ & $5,3 \%$ \\
\hline \multirow{2}{*}{$\begin{array}{l}\text { Ogółem } \\
\% \text { z stosunek do prak- } \\
\text { tyk religijnych }\end{array}$} & Liczebność & 255 & 277 & 240 & 92 & 864 \\
\hline & $100,0 \%$ & $100,0 \%$ & $100,0 \%$ & $100,0 \%$ & $100,0 \%$ & $100,0 \%$ \\
\hline
\end{tabular}

$\mathrm{Chi}^{2}=51,887 \quad \mathrm{df}=12 \quad \mathrm{p}=0,000 \quad \mathrm{~V}$ Kramera $=0,141 \quad \mathrm{p}=0,000$

*Uwaga: Cyfry w kolumnie stosunek do praktyk religijnych oznaczają: 1 - praktykuję systematycznie; 2 - praktykuję niesystematycznie; 3 - praktykuję rzadko; 4 - nie praktykuję wcale.

Osoby praktykujące systematycznie mają bardziej wyrobione oceny moralne tego postępowania niż osoby niepraktykujące. Praktykujący

${ }^{29}$ K. Skoczylas, Wartości religijno-moralne..., dz. cyt., s. 240. 
systematycznie (54,1 proc.) znacznie częściej niż niepraktykujący wcale (32,6 proc.) oceniają je jako niedozwolone. Stosunek do praktyk różnicuje oceny tego zachowania w sposób statystycznie bardzo istotny.

Wśród młodzieży miejskiej rozbieżność opinii na ten temat jak bardzo duża. Niemal co trzeci (34,6 proc.) uważa, że przerywanie ciąży jest niedozwolone. Prawie co dziesiąty (11,8 proc.) sądzi, że przerywanie ciąży jest dozwolone. Zastanawiająco duża liczba młodych (40,3 proc.) sądzi, że ocena przerwania ciąży zależy od okoliczności. Można przypuszczać, że w tej kategorii odpowiedzi skłaniają się ku uznaniu dopuszczalności przerywania ciąży. Taką opinię nieustannie lansuje wiele mediów. Warto podkreślić, że wśród młodzieży wiejskiej Kujaw przeważa opinia (47 proc.), że przerywanie ciąży jest niedozwolone.

Tabela 13. Ocena stosowania środków antykoncepcyjnych a stosunek do praktyk religijnych ${ }^{130}$

\begin{tabular}{|c|c|c|c|c|c|c|}
\hline \multirow{2}{*}{\multicolumn{2}{|c|}{$\begin{array}{c}\text { OCENA STOSOWANIA } \\
\text { ŚRODKÓW ANTYKONCEPCYJNYCH }\end{array}$}} & \multicolumn{4}{|c|}{$\begin{array}{c}\text { STOSUNEK } \\
\text { DO PRAKTYK RELIGIJNYCH* }\end{array}$} & \multirow{3}{*}{$\begin{array}{c}\text { OGÓŁEM } \\
482 \\
\end{array}$} \\
\hline & & 1 & 2 & 3 & 4 & \\
\hline \multirow[b]{2}{*}{ 1. Dozwolone } & Liczebność & 104 & 159 & 153 & 66 & \\
\hline & $\begin{array}{l}\% \text { z stosunek do praktyk } \\
\text { religijnych }\end{array}$ & $40,8 \%$ & $57,4 \%$ & $63,8 \%$ & $71,7 \%$ & $55,8 \%$ \\
\hline \multirow[b]{2}{*}{ 2. To zależy } & Liczebność & 76 & 65 & 40 & 12 & 193 \\
\hline & $\begin{array}{l}\text { \% z stosunek do praktyk } \\
\text { religijnych }\end{array}$ & $29,8 \%$ & $23,5 \%$ & $16,7 \%$ & $13,0 \%$ & $22,3 \%$ \\
\hline \multirow[b]{2}{*}{ 3. Niedozwolone } & Liczebność & 44 & 13 & 13 & 6 & 76 \\
\hline & $\begin{array}{l}\% \text { z stosunek do praktyk } \\
\text { religijnych }\end{array}$ & $17,3 \%$ & $4,7 \%$ & $5,4 \%$ & $6,5 \%$ & $8,8 \%$ \\
\hline \multirow{2}{*}{$\begin{array}{l}\text { 4. Nie umiem powie- } \\
\text { dzieć }\end{array}$} & Liczebność & 17 & 26 & 17 & 4 & 64 \\
\hline & $\begin{array}{l}\text { \% z stosunek do praktyk } \\
\text { religijnych }\end{array}$ & $6,7 \%$ & $9,4 \%$ & $7,1 \%$ & $4,3 \%$ & $7,4 \%$ \\
\hline \multirow[b]{2}{*}{ 5. Brak danych } & Liczebność & 14 & 14 & 17 & 4 & 49 \\
\hline & $\begin{array}{l}\% \text { z stosunek do praktyk } \\
\text { religijnych }\end{array}$ & $5,5 \%$ & $5,1 \%$ & $7,1 \%$ & $4,3 \%$ & $5,7 \%$ \\
\hline
\end{tabular}

$30 \quad$ K. Skoczylas, Wartości religijno-moralne..., dz. cyt., s. 238. 


\begin{tabular}{|c|c|c|c|c|c|c|}
\hline \multirow{2}{*}{\multicolumn{2}{|c|}{$\begin{array}{c}\text { OCENA STOSOWANIA } \\
\text { ŚRODKÓW ANTYKONCEPCYJNYCH }\end{array}$}} & \multicolumn{4}{|c|}{$\begin{array}{c}\text { STOSUNEK } \\
\text { DO PRAKTYK RELIGIJNYCH* }\end{array}$} & \multirow{3}{*}{$\begin{array}{c}\text { OGÓłEM } \\
864\end{array}$} \\
\hline & & 1 & 2 & 3 & 4 & \\
\hline \multirow{2}{*}{$\begin{array}{l}\text { Ogółem } \\
\text { \% z stosunek } \\
\text { do praktyk religij- } \\
\text { nych }\end{array}$} & Liczebność & 255 & 277 & 240 & 92 & \\
\hline & $100,0 \%$ & $100,0 \%$ & $100,0 \%$ & $100,0 \%$ & $100,0 \%$ & $100,0 \%$ \\
\hline
\end{tabular}

$\mathrm{Chi}^{2}=64,758 \quad \mathrm{df}=12 \quad \mathrm{p}=0,000 \quad$ V Kramera $=0,158 \quad \mathrm{p}=0,000$

*Uwaga: Cyfry w kolumnie stosunek do praktyk religijnych oznaczają: 1 - praktykuję systematycznie; 2 - praktykuję niesystematycznie; 3 - praktykuję rzadko; 4 - nie praktykuję wcale.

Tabela pozwala dostrzec, że osoby praktykujące systematycznie oceniają to zachowanie bardziej zgodnie z nauczaniem Kościoła niż osoby mające luźny stosunek do praktyk religijnych. Wśród osób praktykujących systematycznie (17,3 proc.) częściej niż niepraktykujących (6,5 proc.) istnieje przekonanie, że stosowanie środków antykoncepcyjnych jest niedozwolone. Zarazem 40,8 proc. praktykujących systematycznie uważa, że ich stosowanie jest dozwolone. Także wśród tej kategorii widoczna jest erozja ocen moralnych. Ich oceny moralne wyzwoliły się spod moralności przekazywanej przez Kościół. Generalnie stosunek do praktyk religijnych różnicuje w sposób statystycznie bardzo istotny oceny tego zachowania.

\section{Wnioski}

Dokumenty katechetyczne podkreślają, że istotnym celem katechizacji jest doprowadzenie do osobowego spotkania z Chrystusem i głębokiej z Nim zażyłości (por. CT 5). Katecheza, opierając się na nawróceniu „początkowym”, ma na celu dać podstawę temu pierwszemu przylgnięciu do Pana Jezusa i prowadzić je do dojrzałości. Dzięki katechezie uczeń powinien lepiej poznać Chrystusa, czyli lepiej poznać królestwo Boże, które On zapowiada, wymagania i obietnice zawarte w Jego orędziu oraz drogi, jakie wyznaczył dla tych, którzy zechcą za Nim pójść (por. DOK 80). 
Katecheza wymaga, aby realizując jej cele, brać pod uwagę człowieka. Powinna być wierna Bogu i człowiekowi. Badana młodzież podkreśla, że jej religijność kształtuje się pod wpływem tradycji i wychowania w rodzinie. Dość wyraźnie zaznacza się troska o wychowanie religijne w rodzinach ze strony matek. Młodzież odznacza się niskim uczestnictwem w stowarzyszeniach i organizacjach (ok. 4 proc.). Stosunek do wiary jest zróżnicowany. Zwraca uwagę $\mathrm{w}$ tej populacji niemal 17 proc. osób, które przeżywają wątpliwości religijne bądź utraciły wiarę. Dość znaczny odsetek przeżywa wątpliwości religijne w odniesieniu do podstawowych prawd wiary, np. w Boga osobowego nie wierzy niemal 29,1 proc. Takie odniesienie ujawnia się najmocniej w dużym mieście (25,7 proc.). Bardzo wysoki poziom wątpliwości istnieje w małym (37,3 proc.) średnim (26,6 proc.) i dużym mieście (29,6 proc.). Wśród tej młodzieży, która nie praktykuje wcale, znacząca grupa (66,3 proc.) nie wierzy w Boga osobowego.

W społeczeństwie ponowoczesnym może nasilać się zjawisko kryzysu sensu życia. Coraz częściej wartości tworzące sens życia przesuwają go z transcendencji na immanencję. Człowiek staje się coraz bardziej jego ośrodkiem. Sens życia bywa odkrywany coraz częściej w wartościach samorealizacyjnych, dlatego osoba czuje się zmuszona wybierać wartości, które uznaje za sensowne.

Choroba może zachwiać życiem ludzkim i przekreślić wszystkie ludzkie dążenia. Stąd ciężkiej choroby lękają się z podobną częstotliwością młodzi z każdego środowiska, choć nieco częściej mówi o tym młodzież wiejska (26,6 proc.). Lęk przed ciężką chorobą pojawia się niezależnie od stosunku do praktyk religijnych, choć nieco częściej ujawniają go osoby praktykujące niesystematycznie (27,9 proc.) niż praktykujący systematycznie (22,7 proc.). Poczucie bezsensu życia prowadzące do zwątpienia w samo życie jest najczęściej deklarowane przez młodzież z małego miasta (11,9 proc.). Tam tego rodzaju deklaracja pojawia się niemal dwukrotnie częściej niż w dużym mieście (6,1 proc.). Około 10 proc. młodych doświadcza bezsensu życia, co może kierować ku myśleniu o śmierci. Bardzo częste myślenie o śmierci pojawia się z podobną częstotliwością we wszystkich środowiskach, jednak najczęściej mówi o tym młodzież z małego (11,9 proc.) i dużego miasta 
$(13,2 \text { proc. })^{31}$. Ta grupa młodzieży deklarująca częste myślenie o śmierci, a doświadczająca bezsensu życia, powinna być pilnie przedmiotem troski duszpasterskiej. W sytuacji nasilania się częstotliwości występowania depresji wśród młodzieży i tendencji samobójczych wymaga to szczególnej czujności ze strony duszpasterzy i całego personelu szkół.

Dla działalności duszpasterskiej ważne są też przekonania młodzieży badanej co do ludzkiej natury. Młodzi patrzą na ludzką naturę realistycznie. Mają przekonanie, że w człowieku istnieje zarówno dobro, jak i zło. Kiedy wypowiadają się o ludzkich odniesieniach, wówczas pojawia się opinia, że ludzie są wobec siebie obojętni (30,7 proc.). Przeświadczenie to powoduje, że odznaczają się pewną nieufnością do ludzi.

Część młodzieży przejawia także niezrozumienie dla prawd eschatycznych. Wiarę w zmartwychwstanie umarłych, tak jak naucza Kościół, przejawia 24,2 proc. badanych ${ }^{32}$.

Wiara poznawana na lekcjach religii jest praktykowana we wspólnocie Kościoła. Lekcja religii powinna motywować do uczestnictwa w liturgii Kościoła. Wkład nauki religii polega na tym, że ukazuje ona uświęcające znaczenie świadomego uczestnictwa w liturgii. Budowana świadomość powinna pomagać uczniowi uczestniczyć w liturgii rozumianej jako pogłębienie więzi z Chrystusem i Kościołem, uzdalniającej do zaangażowania się po stronie dobra ${ }^{33}$. Wydaje się, że lekcja religii w ograniczonym zakresie osiąga swój cel. W niedzielnej mszy świętej uczestniczy w każdą niedzielę 15 proc. badanych. Wzrasta grupa uczestniczących w niej nieregularnie (36,8 proc. - prawie w każdą niedzielę i jeden-dwa razy w miesiącu). Dość duża grupa (31,5 proc.) uczestniczy we mszy świętej tylko z powodu ślubu, pogrzebu czy w wielkie święta. Natomiast 6,5 proc. w ogóle przestało uczestniczyć w liturgii.

Celem katechezy na tym poziomie nauczania jest także wychowanie moralne. Katecheza winna doprowadzić do podejmowania samodzielnych decyzji opartych na fundamencie motywacji chrześcijańskiej. Podstawą moralności chrześcijańskiej jest Dekalog. Młodzież w umiarkowanym

31 K. Skoczylas, Wartości religijno-moralne..., dz. cyt., s. 97-121.

32 K. Skoczylas, Wartości religijno-moralne..., dz. cyt., s. 148.

33 Por. K. Skoczylas, Wartości religijno-moralne..., dz. cyt., s. 74. 
stopniu wyraża akceptację wobec poszczególnych norm Dekalogu. Najczęstszą akceptację spośród przykazań Dekalogu zyskują wśród badanych przykazania: czwarte (czcij ojca i matkę swoją) - 75,3 proc., piąte (nie zabijaj) - 75,1 proc. i siódme (nie kradnij) - 73,7 proc. Kobiety znacznie częściej wyrażają akceptację dla Bożych przykazań niż mężczyźni. Stosunek do praktyk religijnych różnicuje w sposób statystycznie istotny stosunek do Dekalogu. Najczęściej osoby określające siebie jako „praktykujący systematycznie” wyrażają pełną akceptację dla Dekalogu. Zarazem badani przy wysokim odsetku akceptacji dla Dekalogu często uznają, że nie ma jednoznacznych kryteriów dobra i zła (43,4 proc.). Można więc zakładać, że wielu z nich opowiada się za etyką sytuacyjną.

Oceny zachowań moralnych w niektórych zakresach, a zwłaszcza odnoszących się do życia małżeńsko-rodzinnego, są w wielu przypadkach sprzeczne z nauczaniem Kościoła. Dla ponad połowy młodzieży $(53,2$ proc.) współżycie seksualne po ślubie cywilnym, a przed kościelnym jest całkowicie moralnie dozwolone. Podobnie jeśli chodzi o stosowanie środków antykoncepcyjnych. Takie postępowanie przez większość badanych (55,8 proc.) jest traktowane jako zachowanie moralnie dozwolone. Tylko 8,8 proc. uważa, że jest ono niedopuszczalne. Im młodzież rzadziej praktykuje, tym częściej traktuje stosowanie tych środków jako działanie moralnie dopuszczalne. Zdrada małżeńska przez większość jest oceniana jako zachowanie niedopuszczalne moralnie (66 proc.), natomiast 6 proc. uznaje ją za dopuszczalną. We wszystkich środowiskach spotyka się ona z potępieniem. Praktykujący systematycznie najczęściej traktują ją jako całkowicie niedopuszczalną ( 71,8 proc.). Natomiast postawy wobec rozwodów są już bardziej spolaryzowane. Choć nadal co dziesiąty uznaje rozwód za niedopuszczalny (12,2 proc.), to jednak niemal co trzeci uważa go za działanie usprawiedliwione $(28,5 \text { proc. })^{34}$.

Trzeba też zauważyć, że kształtowanie stosunku do wartości katolickich dokonuje się na lekcjach religii w szkole. Warto jednak pamiętać, że szkoła nie jest środowiskiem przychylnym do takiej aktywności. Szkoła realizuje oprócz funkcji dydaktycznej także funkcję wychowawczą. W polskiej szkole częściej podkreśla się bardziej jej rolę dydaktyczną niż

${ }^{34}$ K. Skoczylas, Wartości religijno-moralne..., dz. cyt., s. 230-241. 
wychowawczą. Spostrzega się także, co podkreśla Wojciech Osial, że panuje pewne zamieszanie w rozumieniu funkcji wychowawczej szkoły. Dla wielu funkcja ta sprowadza się do spontanicznej samorealizacji, do wychowania bezstresowego czy do urzeczywistniania w tym procesie jedynie wolności i tolerancji ${ }^{35}$. Także w działalności praktycznej szkół często dominuje funkcja dydaktyczna nad wychowawczą, a i rodzice niezbyt doceniają wychowawcze wysiłki szkoły. W takim kontekście realizowana jest lekcja religii w szkole, która powinna mieć charakter wychowawczy, chociaż kontekst szkolny nie uławia realizacji tego charakteru.

Trudności młodych w akceptacji wartości wypływających z wiary powinny być wyzwaniem dla całego środowiska katolickiego, aby podejmować wysiłek przekazywania wartości, bycia wiernym wobec wartości obecnych w tradycji. Zarazem sytuacja ta jest wezwaniem do podejmowania nowych zadań ewangelizacyjnych ${ }^{36}$. W szkole trzeba też podejmować duszpasterstwo katechetyczne, które powinno ukazać młodym wartości ważne dla wierzących ${ }^{37}$.

35 W. Osial, Misja wychowawcza lekcji religii w szkole, „Warszawskie Studia Teologiczne” 25 (2012) 42, s. 269-280.

36 Por. W. Śmigiel, Jak głosić Jezusa Chrystusa w dobie nowej ewangelizacji, „Rocznik Teologii Katolickiej" 13 (2014) 2, s. 159-169.

37 Por. M. Polak, Posługa Kościoła w szkole. Inspiracje dla polskiego duszpasterstwa, „Studia Pastoralne" 3 (2007) 3, s. 277-279. 


\section{Summary}

Odniesienie młodzieży XXI wieku do wartości na przykładzie wybranych wartości religijno-moralnych młodzieży Kujaw wschodnich

Młodość jest czasem kształtowania odniesienia do wartości. Rodzi się ono w wyniku rozwijającej się w tym okresie podmiotowości. Młodzi zdobywają się na osobisty stosunek do wielu wartości, w tym również do wiary w Boga. Stosunek ten kształtuje się na skutek wpływu rodziny, oddziaływania wspólnoty religijnej uzewnętrzniającej się przez parafie oraz nauczanie religii. Z drugiej strony jej postawa kształtuje się na skutek wychowawczego wpływu wielu wspólnot i instytucji przekazujących alternatywne spojrzenie na świat i inne odniesienia do wartości. Badania przeprowadzone wśród młodzieży Kujaw wschodnich ujawniają akceptację wartości katolickich przez znaczną grupę młodzieży, a także pozwalają dostrzec pewną część młodzieży, która oddala się od uznanych wartości. Wspólnota katolicka pragnąca zachować swoją tożsamość powinna stale troszczyć się o jak najpełniejszy przekaz wartości katolickich. W proces ten powinni być włączeni wierzący rodzice, wspólnota religijna oraz nauczyciele religii. Również i to inspiruje do realizowania duszpasterstwa katechetycznego.

Słowa kluczowe: wartości, wiara, rodzina, młodzież, katecheza, nauczanie religii, duszpasterstwo

The 21st Century Young People's Attitude Towards the Values on the Example of Selected Religious-Moral Values of Young People of Eastern Kuyavia

Youth is the time to shape an attitude towards the values. This is due to the development of subjectivity in this period. Young people acquire the personal relationship with many values including the faith in God. This relationship is shaped by the influence of the family, the influence of the religious community manifesting itself through the parishes and the teaching of religious education. On the other hand, its attitude is shaped by the educative influence of many communities and institutions that provide an alternative view on the world and alternative reference to the values. The study conducted among young people of Eastern Kuyavia reveals the acceptance of Catholic values by a large group of young people but also allows to notice a certain part of the young people who abandon these recognized values. The Catholic community who wants to keep its identity should always be concerned about the fullest possible transfer of Catholic values. Believing parents, religious communities, and religious education teachers should be involved in this process. It also inspires carrying out catechetical pastoral care. 
Keywords: values, faith, family, young people, religious education/catechesis, religious education teaching, pastoral care

\section{Bibliografia}

Babbie E., Badania społeczne w praktyce, przeł. W. Betkiewicz, Warszawa 2003.

Kalembka S., Kujawy Wschodnie w powstaniu styczniowym. Rys wybranych zagadnien, w: Z dziejów powstania styczniowego na Kujawach i Ziemi Dobrzyńskiej, red. S. Kalembka, Warszawa 1989, s. 7-79.

Konferencja Episkopatu Polski, Dyrektorium katechetyczne Kościoła katolickiego w Polsce, Kraków 2001.

Konferencja Episkopatu Polski, Podstawa programowa katechezy Kościoła katolickiego w Polsce, Kraków 2010.

Kujawski H., Historia diecezji włocławskiej, w: „Rocznik Diecezji Włocławskiej 2011”, red. A. Niemira, Włocławek 2011, s. 41-82.

Mariański J., Małżeństwo i rodzina w świadomości młodzieży maturalnej - stabilność i zmiana, Toruń 2012.

Morawski M., Monografia Włocławka, wyd. 2., Włocławek 2003.

Osial W., Misja wychowawcza lekcji religii w szkole, „Warszawskie Studia Teologiczne” 25 (2012) nr2, s. 269-280.

Piwowarski W., Stosunek uczniów i studentów do podstawowych wartości społeczeństwa polskiego, „Życie Katolickie” 9 (1990) nr 2, s. 63-68.

Ryczan K., Wartości katolików a typ środowiska miejskiego, Lublin 1992.

Skoczylas K., Wartości religijno-moralne młodzieży ponadgimnazjalnej Kujaw wschodnich, Włocławek 2016. 